\title{
Upper crustal fluids in a large fault system: microstructural, trace element and oxygen isotope study on multi-phase vein quartz at the Bavarian Pfahl, SE Germany
}

\author{
Anna Schaarschmidt ${ }^{1}$ (1) $\cdot$ Karsten M. Haase $^{1} \cdot$ Helga de Wall $^{1} \cdot$ Michel Bestmann $^{1}$ - Stefan Krumm ${ }^{1} \cdot$ Marcel Regelous $^{1}$
}

Received: 2 July 2018 / Accepted: 19 November 2018 / Published online: 12 December 2018

(c) The Author(s) 2018

\begin{abstract}
Fault systems are zones of crustal weakness and are used as pathways for ascending hydrothermal fluids. One impressive example is the more than $150 \mathrm{~km}$ long Bavarian Pfahl system at the SW boundary of the Bohemian Massif. Dextral ductile shearing of Moldanubian basement has shaped a several hundred meter wide zone of mylonites and ultramylonites. This setting was reactivated under brittle conditions and infiltrated by fluids resulting in a multi-phase quartz lode. Structural analysis using scanning electron microscopy cathodoluminescence (SEM-CL) images has been carried out in combination with trace element and oxygen isotope analysis on quartz along the system. Three successive quartz phases have been distinguished due to their structural details and trace element contents. Cryptocrystalline quartz fabric in the first quartz phase results from crystallization from a silica gel, whereas in phases II and III, quartz precipitation is characterized by repeated fragmentation and sealing, visible due to strongly varying CL intensities. The $\delta^{18} \mathrm{O}$ of Bavarian Pfahl quartz decreases from $13.8 \%$ in the NW to $8.5 \%$ in the SE, whereas quartz from the close-by-situated Wölsendorf fluorite deposit shows $\delta^{18} \mathrm{O}$ between 15.9 and $18.5 \%$ (vs. SMOW). Flat shale-normalized rare earth element patterns point towards an upper crustal origin of the hydrothermal fluids. The southeastern part of the Bavarian Pfahl is interpreted to represent a deeper crustal level with higher mineralization temperatures (about $350^{\circ} \mathrm{C}$ ) compared to the rest of the Pfahl $\left(<250{ }^{\circ} \mathrm{C}\right)$.
\end{abstract}

Keywords Quartz microfabric · Cathodoluminescence $\cdot$ Hydrothermal fluid · Trace elements · Oxygen isotopes

\section{Introduction}

Hydrothermal veins are abundant both in the continental and in the oceanic crust of the Earth and indicate the flow of hydrous fluids through the crust. The influence of pressure, temperature and fluid-rock interactions leads to the dissolution and precipitation of minerals at different crustal levels. Some fluids apparently are enriched in metals and other elements so that the precipitation from these fluids leads to the formation of hydrothermal ore deposits of $\mathrm{Cu}, \mathrm{Au}, \mathrm{Pb}$, or Zn but also of other economically important minerals such as barite or fluorite (Wilkinson et al. 2009; Seward et al. 2013). The formation of hydrothermal deposits and their metal contents depends not only on fluid parameters such

Anna Schaarschmidt

anna.schaarschmidt@fau.de

1 GeoZentrum Nordbayern, Friedrich-Alexander Universität, Schlossgarten 5, 91054 Erlangen, Germany as temperature or $\mathrm{pH}$ but also on the host rock composition. Past and present fluid flow is frequently observed along pre-existing shear and fault zones, which serve as pathways due to localized enhanced permeability. Such fault zones can be active for long periods of time which is indicated by different phases of tectonic activity and the brecciation of previously formed rocks. Similarly, hydrothermal mineralizations are characterized by periodic formation which indicates repeated ascent of hydrothermal fluids. Seismic pumping is a widely accepted mechanism for fluid migration associated with seismic faulting and shallow earthquakes (Sibson et al. 1975). Increasing shear stress around a fault region induces dilation prior to brittle failure, which leads to the inflow of fluid from the surrounding crust. Fluid pressure, which dropped due to dilation, rises again and reduces the static friction along the fault. When the shear stress exceeds the frictional resistance, seismic failure occurs and the fluids migrate rapidly in the direction of easiest pressure relief. Upward propagation of fluid-filled fractures, so-called mobile hydrofractures (Dahm 2000; Bons 2001), enables 
the transport of large fluid volumes to the upper crust. Precipitated mineral phases and fluid inclusions may conserve the thermodynamic and chemical characteristics of the fluid and its source. Geochemical analysis of hydrothermal vein minerals is, therefore, a powerful tool to understand fluid evolution and vein formation. A detailed knowledge of the structural relationship of succeeding mineralization phases is required to result in a realistic interpretation of geochemical analysis.

The Bavarian Pfahl is a mineralized shear zone consisting of multiple quartz phases that represent a large former hydrothermal system (Horn et al. 1986; Yilmaz et al. 2014). The $\sim 150 \mathrm{~km}$ long quartz mineralization changes to a $\sim 15 \mathrm{~km}$ long fluorite-dominated mineralization in the NW (near Wölsendorf, Fig. 1) indicating differences in the composition of the parental fluids. Several studies have contributed to the geochronological, geochemical and structural understanding of the Bavarian Pfahl system (Hofmann 1962; Horn et al. 1986; Peucker-Ehrenbrink and Behr 1993; Yilmaz et al. 2014), but the fluid sources and detailed mineralization conditions are poorly understood. What are the temperatures and fluid compositions during quartz formation? Do they change temporally or spatially along the large hydrothermal system and how? What processes and conditions control quartz precipitation? This study is a combined structural and geochemical approach towards a better understanding of the fluid activity along the Bavarian Pfahl through time.
Microstructural observations combined with cathodoluminescence imaging give insight into the complex internal structure of quartz. Three different phases of quartz precipitation can be defined in the Pfahl with the first containing the highest concentrations of metals. We show significant changes in the trace element and oxygen isotope composition along the mineralization that imply lower temperatures but higher metal contents in the fluids towards the Wölsendorf segment in the NW. The regional changes are discussed considering the constitution of the surrounding Moldanubian basement and the transition to the Permo-Mesozoic sediment basin. Finally, we conclude that different depth levels of Moldanubian upper crust are exposed along the Bavarian Pfahl.

\section{Geological setting}

The Bavarian Pfahl system is a major shear zone at the southwestern margin of the Bohemian Massif, the largest part of exposed Variscan basement in Central Europe (Fig. 1). It crosses the Bavarian Forest and extends more than $150 \mathrm{~km}$ from Eastern Bavaria to Upper Austria (Schröder 1987; Brandmayr et al. 1995; Mattern 2001). The Bavarian Pfahl is well known for its prominent exposures of up to $100-\mathrm{m}$-wide quartz mineralizations along a straight line building a morphological wall in the Bavarian
Fig. 1 Geological map of the study area with sample locations along the Bavarian Pfahl (quartz samples: blue squares, mylonite samples: gray rhombus) and at the Nabburg-Wölsendorf fluorite deposit (green square). Location numbers correspond to the numbering in Table 1 .

The Bavarian Pfahl lies at the SW boundary of the Bohemian Massif (BM) and is surrounded by the Moldanubian basement. Separation of the Pfahl system into three segments $(\mathrm{A}-\mathrm{C})$ is based on different structural characteristics as lined out in the text. (Data source: Bayerisches Landesamt für Umwelt, http://www.lfu.bayern.de)

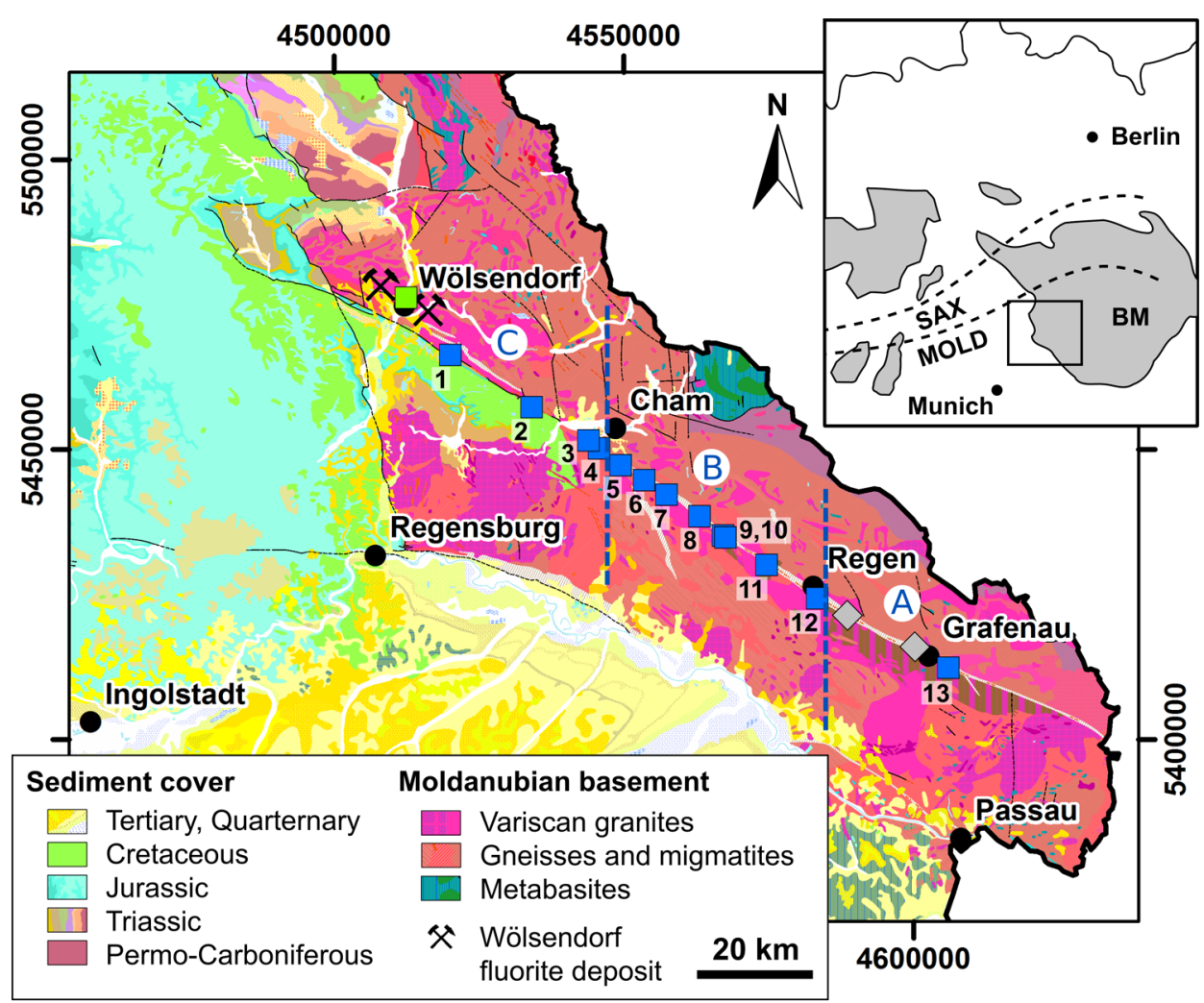


Forest. The quartz mineralization follows a steep NW-SE trending shear zone and forms interrupted segments of a hydrothermal quartz lode (Fig. 2). The shear zone transects Moldanubian migmatites, diatexites, gneisses and late-Variscan granites (Fig. 1). Regional metamorphism and crustal anatexis during the Variscan orogeny led to voluminous emplacement of syntectonic granitoids at 342-321 Ma into the Moldanubian units (Siebel et al. 2005, 2006, 2010). Intrusion ages and record of shear deformation in these granitoids help to establish a time frame for movements along the Pfahl structure. Earliest evidence for a NW trending zone of reduced crustal strength provides along-strike intrusions of $334 \mathrm{Ma}$ old palites (granodiorites with mafic enclaves) indicating a Lower Carboniferous activity of the Bavarian Pfahl shear zone (Siebel et al. 2005). The major phase of ductile shearing has dextral strike-slip kinematics with deformation under lower amphibolite to upper greenschist conditions and is accompanied by a complex pattern of synthetic (dextral) and antithetic (sinistral) shear zones in granite and granitic dykes emplaced between 324 and $315 \mathrm{Ma}$ (Galadí-Enríquez et al. 2010). Formation of the Pfahl shear zone is seen as part of a conjugate shear system related to $\mathrm{N}$ - to NNW-directed compressional forces in the late stage of the Variscan orogeny (Wallbrecher et al. 1991; Brandmayr et al. 1999; Galadí-Enríquez et al. 2010).

The whole ductile shear zone system was overprinted by brittle deformation during post-Variscan (Permian) times and subsequent events related to the Alpine compression (Brandmayr et al. 1995). Brittle deformation was accompanied by ascent of hydrothermal siliceous fluids in the upper crust, leading to the mineralization of the Pfahl quartz lode at $247 \pm 21 \mathrm{Ma}(\mathrm{Rb} / \mathrm{Sr}$ analysis, Horn et al. 1986). In northwestern continuation of the Pfahl, the mineralization changes to fluorite-barite-dominated veins of the Nabburg-Wölsendorf area (Fig. 1). A mineralization age of $269 \pm 14 \mathrm{Ma}(\mathrm{Rb} /$ $\mathrm{Sr}$ analysis, Leipziger 1986) for the fluorite-barite deposit suggests a close relationship between the two hydrothermal events.

Yilmaz et al. (2014) described at least three successive Pfahl quartz phases in detail and concluded that quartz precipitation is characterized by repeated cataclasis, fracturing and sealing. A fluid inclusion microthermometry study on the youngest quartz mineralization by Oppermann (1990) determined a low-temperature, high-salinity fluid, stored in primary fluid inclusions, changing into a high-temperature, low-salinity fluid, stored in secondary fluid inclusions. Estimated mineralization temperatures lie between 120 and $280{ }^{\circ} \mathrm{C}$. The exposed crustal level was located at 4-6 km depth during quartz formation (Gromes 1980). The geochemical work by Peucker-Ehrenbrink and Behr (1993) demonstrates the influence of K-metasomatism and wall-rock alteration on the chemical composition of quartz,
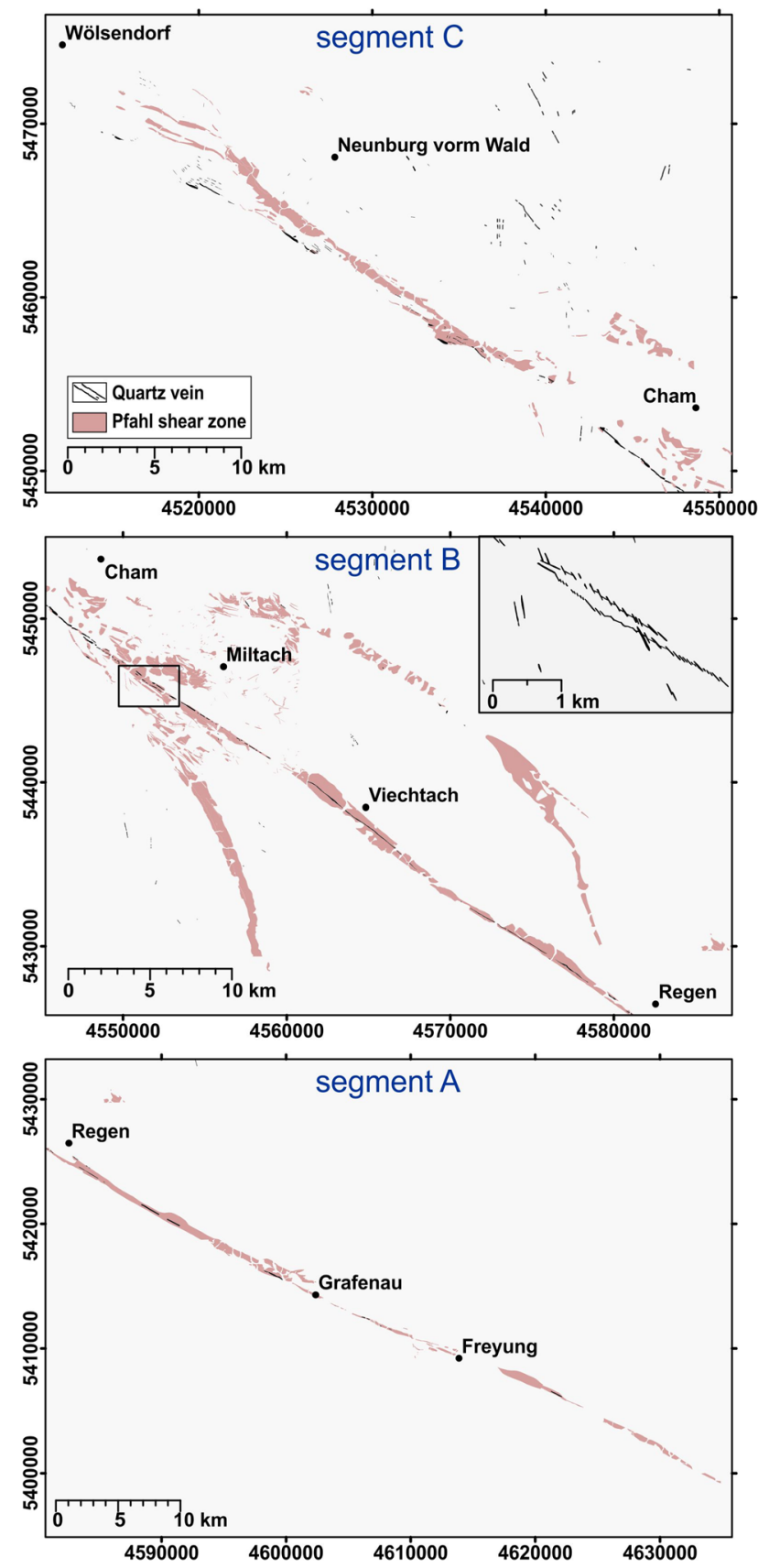

Fig. 2 Distribution of sheared rocks and quartz veins along the Bavarian Pfahl divided into three segments A, B, C, as marked in Fig. 1. Drawn on the base of digital maps 1:25000. (Data source: Bayerisches Landesamt für Umwelt, http://www.lfu.bayern.de and Teipel et al. (2008)

leading to high $\mathrm{K}$ contents relative to $\mathrm{Ca}$ and $\mathrm{Na}$ contents of quartz.

\section{Segments of the Bavarian Pfahl}

The Bavarian sector of the Pfahl shear zone can be subdivided into different segments on account of the structural 
pattern and related quartz mineralization (A, B, C, Figs. 1, 2). In the southeastern segment SE of Regen (A), the ductile deformation during Carboniferous and Early Permian (Brandmayr et al. 1995; Siebel et al. 2005) has formed a parallel mylonitic to ultramylonitic foliation with long-distance continuity in strike $\left(125^{\circ}\right)$ and dip (vertical). The mylonitic foliation is formed by fractured and elongated feldspar aggregates and bands of recrystallized quartz (Fig. 3a-c). Fractured plagioclase is a stable phase and is surrounded by recrystallized quartz which imposes a granular fabric appearance. In $\mathrm{K}$-feldspar-bearing rock types, feldspar is locally transformed into white mica (Fig. 3d). This is especially evident in ultramylonitic parts, which show a laminated fabric by alternation of micaceous and quartz bands (Fig. 3b). K-feldspar is also decomposed into myrmekite (albite-oligoclase and quartz, Fig. 3e) due to stress concentration during the shear deformation causing a fine-grained matrix during proceeding strain (Simpson and Wintsch 1989; Menegon et al. 2006). Besides intense fracturing and dissolution precipitation, K-feldspar also shows evidence of incipient stage of subgrain rotation. Therefore, the mylonitic deformation temperature of the Pfahl shear zone is in the range of about $400-450{ }^{\circ} \mathrm{C}$ (Fitz Gerald and Stünitz 1993; Stipp et al. 2002). There is no evidence for significant host rock alteration. In segment A, steep foliations of mylonites and ultramylonites (Pfahlschiefer) were used as fluid pathways and attest a favorable orientation of the structures with respect to the tectonic stress field. The highly anisotropic host rocks have a low shear resistance and thus facilitated foliation-parallel opening and quartz mineralization. This is seen at location 13 near Grafenau, where quartz mineralization of phases I and II is parallel with the strike $\left(125^{\circ}\right)$ of the Pfahlschiefer.

In contrast, the quartz mineralization in segment $\mathrm{B}, \mathrm{NW}$ of Regen, is more complex (Fig. 2). Here, the Pfahl shear zone does not form a continuous structure and quartz veins of different orientation crosscut granites and gneisses. The host rocks show a strong alteration but no evidence for a consistent pre-existing ductile shear fabric. The complex relationship of quartz veins and granitic host rock in this segment has recently been described in detail by Yilmaz et al. (2014) for the Waschinger quarry (location 11, Fig. 1) where a network of quartz veins transects kaolinized and silicified granite. Detailed mapping of the regional variation in orientation of quartz structures was carried out by Hofmann (1962). His map highlights the oblique orientation of individual quartz structures with respect to the general NW trend of the Pfahl shear zone (Fig. 2). In exposures such as Viechtach (location 8, Fig. 1), the dilational character of the late quartz phases is testified and transtensional kinematics (dextral shear + extension) can be inferred from the geometrical relationship. Prominent in the whole segment are steep $\mathrm{N}-\mathrm{S}$ trending quartz-filled dilation structures transecting the Pfahl-parallel mineralization.
The segment NW of Cham (segment C) is characterized by the transition from basement to sediment units. Breakdown of the Variscan basement induced the formation of multiple Permo-Carboniferous basins (Fig. 1) like the Weiden basin and the Schmidgaden trough (Fuchs and Soffel 1981; Bauberger and Streit 1982). Sedimentation during Permian, Triassic and Jurassic progressively covered parts of the Variscan basement, particularly in the Wölsendorf area. Uplift during the Cretaceous led to erosion and removal of the sedimentary cover (Schröder et al. 1997) and only the sediments within the Bodenwöhr half graben (Meyer 1989) remained. West of Cham the quartz mineralization deviates from the prevailing shear zones and forms individual structures but follows the regional NW trend (Fig. 2). The quartz veins crosscut the granites along the northern boundary of the Bodenwöhr depression, whereas the mylonites (Pfahlschiefer) run separately shifted about $1 \mathrm{~km}$ to the east. In segment $\mathrm{C}$, the oldest quartz phase is characterized by intense reddish colors and cataclastic overprint.

With a general NW-SE strike, the Nabburg-Wölsendorf fluorite deposit lies in northwestern continuation of the Pfahl, near the Schmidgaden trough (Fig. 1). It consists of about 70 mineralized veins in an area of $15 \mathrm{~km}$ length and some 3-5 km width (Ziehr 1975). Seven of the veins contain mainly quartz but the great majority contain fluorite, barite, quartz, dolomite, calcite, and frequently sulfides. The fluorite was mined from about 1900 to 1987 with a maximum production of 140000 tons in 1952 and a production of 2.4 million tons with $80 \%$ fluorite between 1900 and 1970 (Ziehr 1975).

To evaluate possible changes in the fluid chemistry, we focus on exposures in segments B (locations 5-12) and C (locations 1-4). For comparison, we also considered a location within segment A (location 13).

\section{Sampling and methods}

Hydrothermal quartz of multiple phases was sampled at 13 locations (Fig. 1) along the Bavarian Pfahl quartz lode and at 1 location in the Wölsendorf fluorite district, where quartz precipitated next to blue fluorite.

Three quartz samples were analyzed by scanning electron microscopy (SEM, Tescan VEGA2 XMU) at the GeoZentrum Nordbayern, Friedrich-Alexander Universität ErlangenNürnberg. The thin sections underwent mechanical diamond polishing, mechanical-chemical polishing using a colloidal silica suspension $\left(\right.$ Syton $^{\circledR}$, Fynn and Powell 1979) and were coated with a $3.8 \mathrm{~nm}$ thin carbon layer. SEM analysis was performed using an accelerating voltage of $10-15 \mathrm{kV}$ for cathodoluminescence (CL) and $15 \mathrm{kV}$ for backscattered electron (BSE) imaging and for energy-dispersive X-ray 


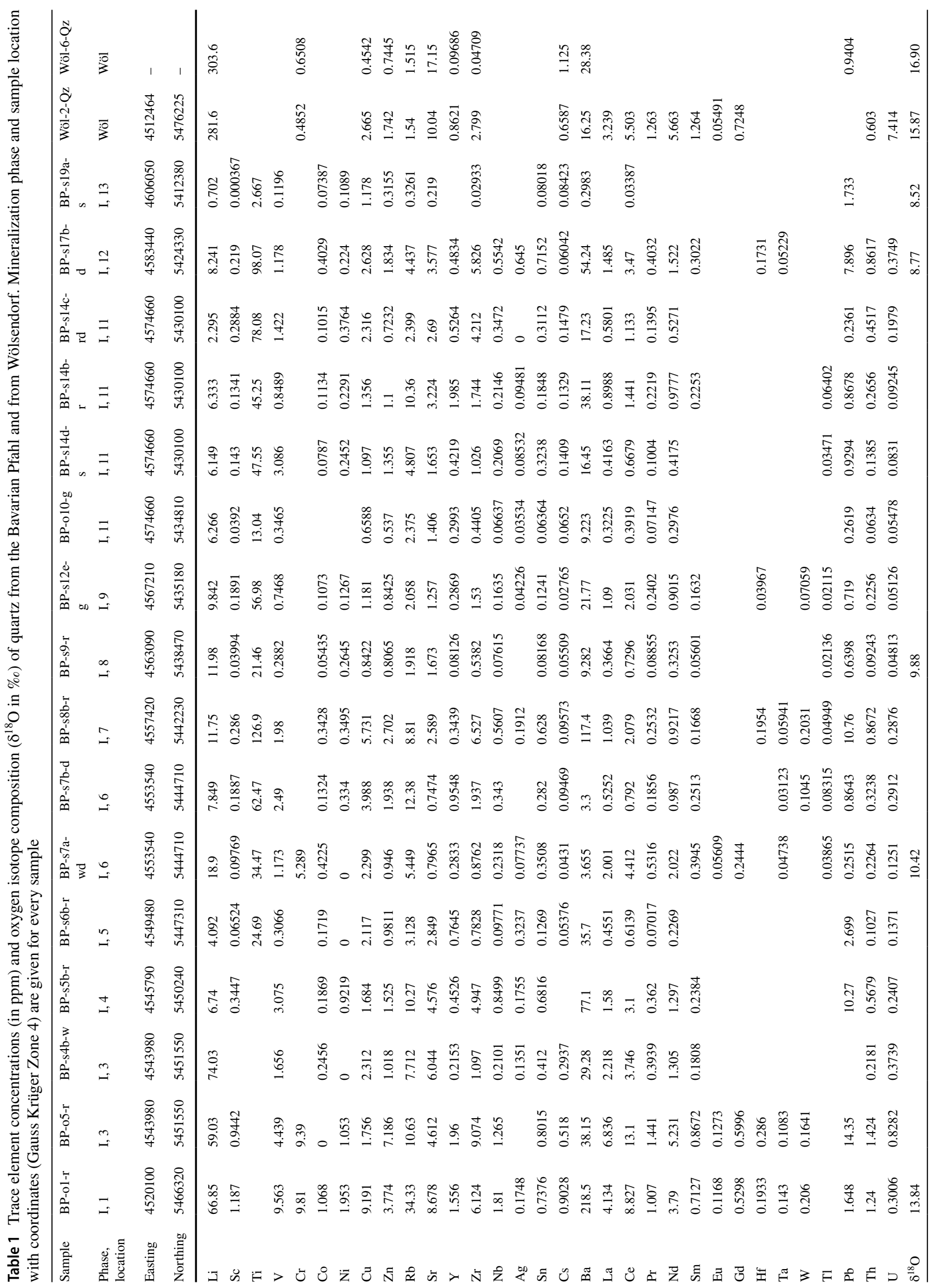




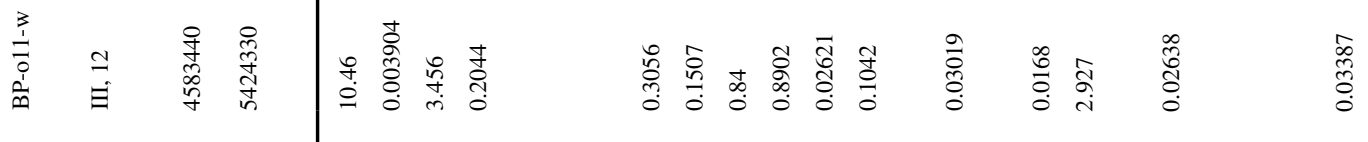

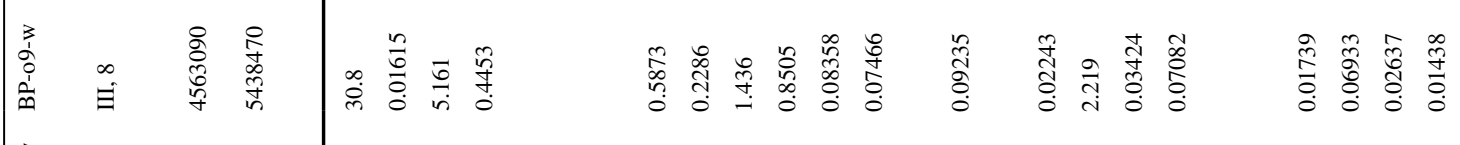

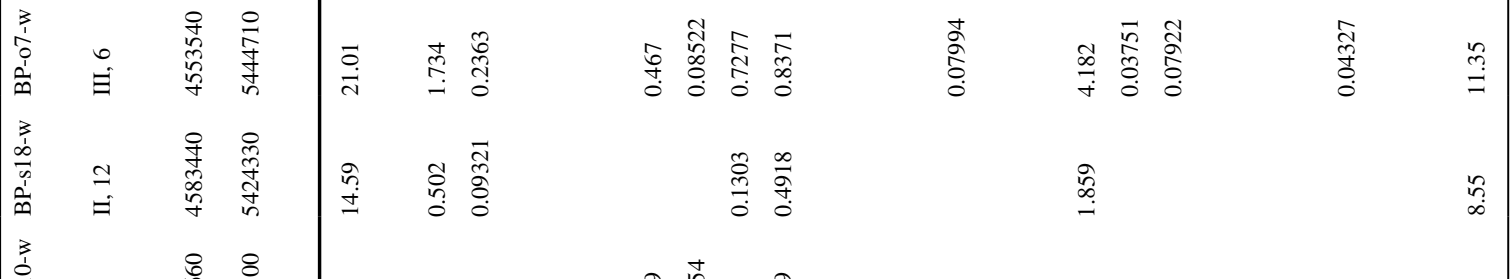

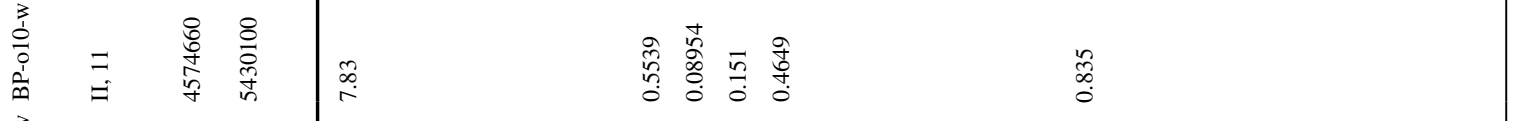

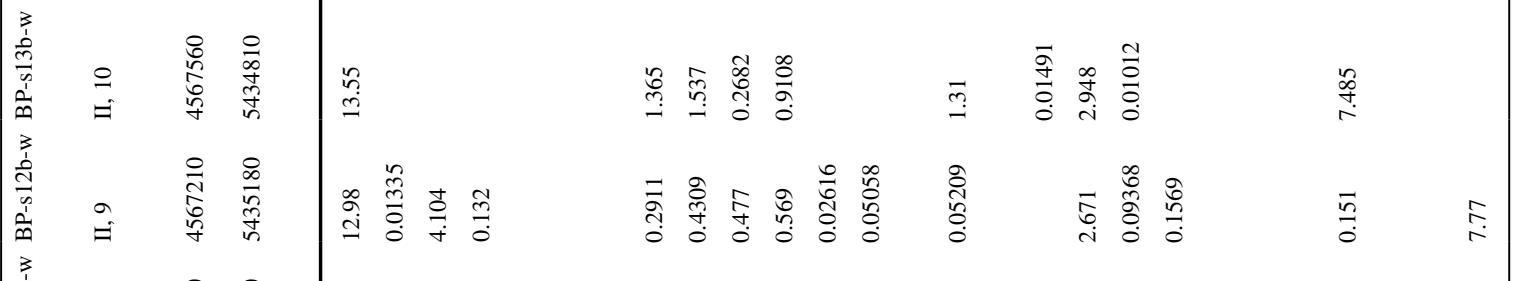

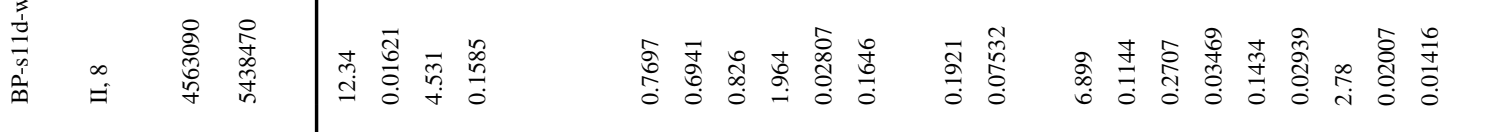

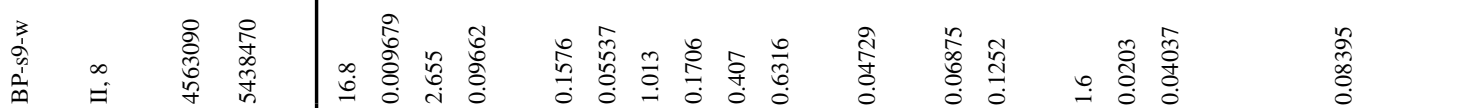

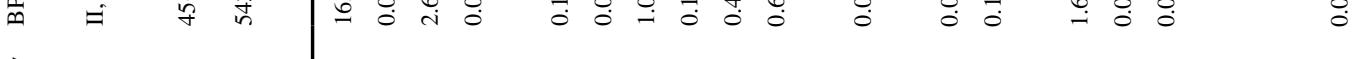

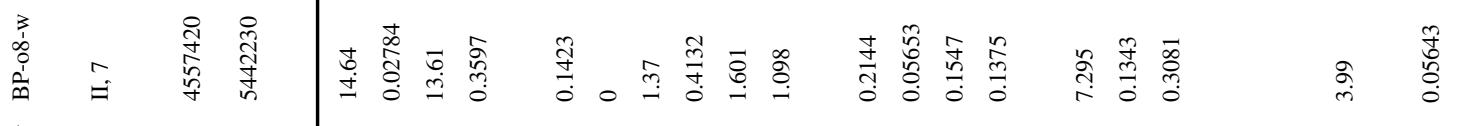

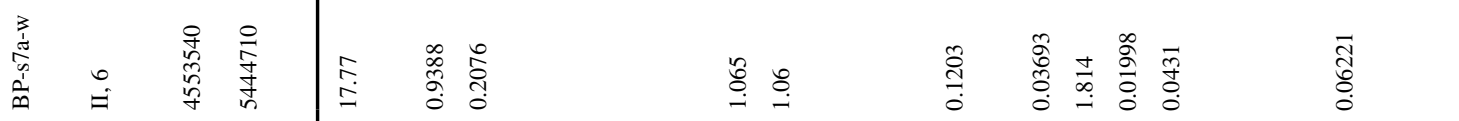

I. I

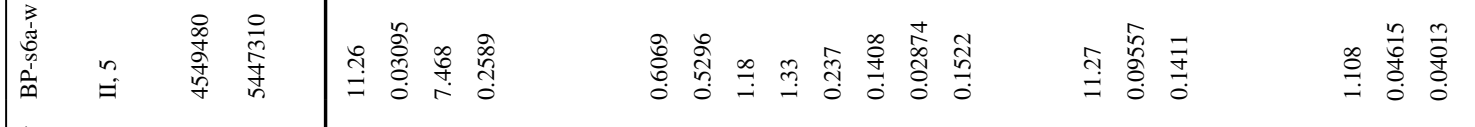

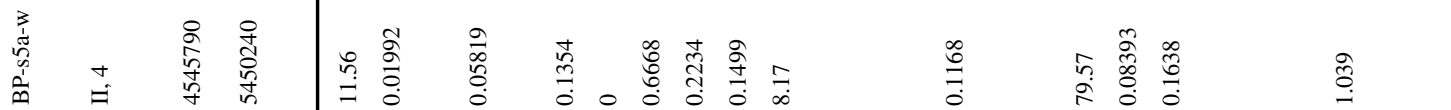

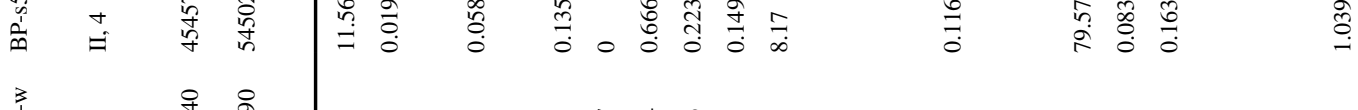

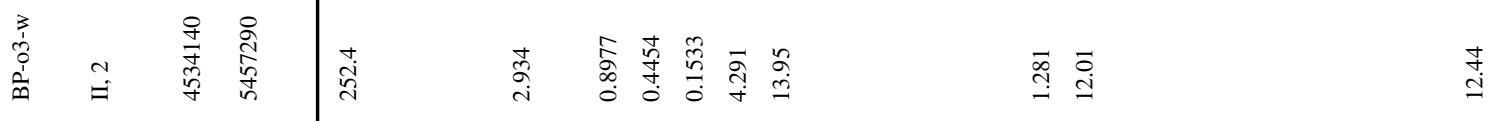

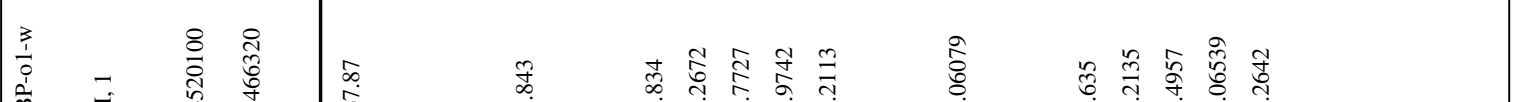

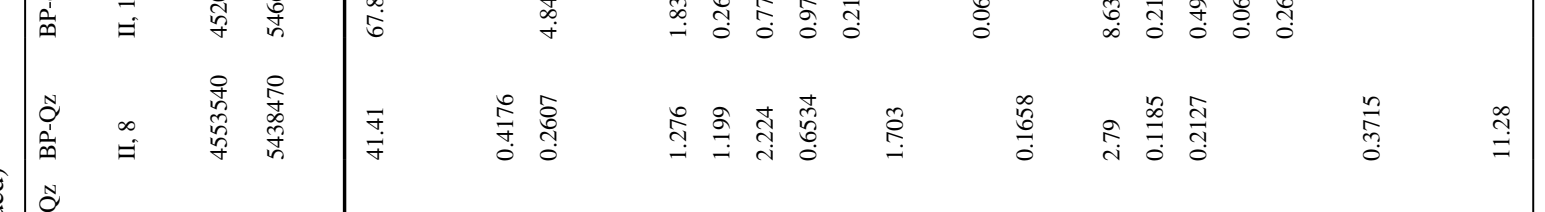

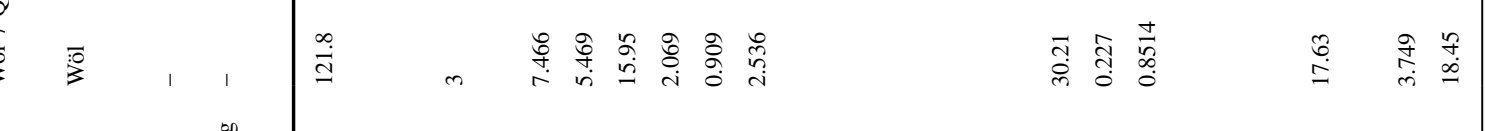

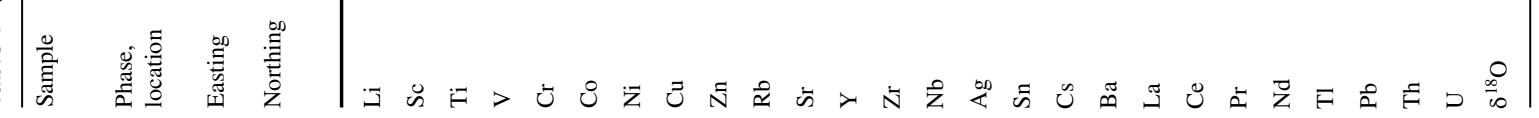


(EDX) analysis. SEM-CL images were used to distinguish multiple quartz phases.

For trace element and oxygen isotope analysis, small pieces of quartz were sawed off the hand samples to separate homogeneous pieces of every quartz phase. These pieces were crushed to a grain size $<2 \mathrm{~mm}$. Quartz from Wölsendorf was separated from fluorite according to the mineral appearance using a binocular stereo microscope. Trace element compositions were determined using an inductively coupled plasma mass spectrometry (ICP-MS, ThermoFisher X-Series2) at the GeoZentrum Nordbayern. About $200 \mathrm{mg}$ of each quartz sample was dissolved in $15 \mathrm{M} \mathrm{HNO}_{3}$ and $12 \mathrm{M}$ $\mathrm{HF}$ by boiling at $130{ }^{\circ} \mathrm{C}$ for $12 \mathrm{~h}$ in a screw-topped Teflon $\odot$ container. The solutions were evaporated and repeatedly treated with $\mathrm{HNO}_{3}$ until fully in solution. Finally, the samples were diluted to get a precisely determined dilution factor of about 1000. The sample solutions were introduced into the plasma via a desolvating nebuliser (CETAC Aridus II). The measurement procedure follows the description in Freund et al. (2013). The international rock standard BHVO-2 was dissolved and analyzed with the samples and the internal precision was between 1 and $5 \%$ for most elements. The concentrations of the 34 analyzed trace elements are given in Table 1.

Oxygen isotope data were determined by laser fluorination (Genske et al. 2013) at the GeoZentrum Nordbayern. The sample mass lay between 1.8 and $2.6 \mathrm{mg}$. The released oxygen was analyzed using a ThermoFinnigan Delta Plus mass spectrometer. The oxygen isotope results are given as $\delta^{18} \mathrm{O}$ vs. SMOW and standard deviations lie between 0.01 and $0.04 \%$. For further interpretation, isotopic compositions of the mineralizing fluid were calculated using estimated mineralization temperatures from the literature and equilibrium quartz-water oxygen isotope fractionation after Clayton et al. (1972).

\section{Structural results}

\section{Structural evolution of quartz veins}

Macroscopic observations in outcrops along the Bavarian Pfahl allow to subdivide the mineralization into three generations, which differ in color, grain size and vein orientation. Since cross-cutting relationships clearly indicate their temporal succession, in the following they are named phase I, II and III, respectively. Outcrops along segments B and C of the Pfahl structure show a fine-grained, colored quartz phase (I), which is cut by two coarse-grained, white quartz phases (II, III) (Fig. 4a-c). Quartz phase I occurs as groundmass of the hydrothermal quartz mineralization and varies in color on outcrop and specimen scale from intense red via slightly reddish to light gray to dark gray (Fig. 4a-c). Quartz phase
II is white and coarse-grained and transects the colored quartz mass in mm- to m-thick veins (Fig. 4a, b) or builds a thick quartz mass that contains fragments of the colored quartz phase I. In large parts of segment B, phase II forms the dominant and, therefore, massive quartz formation. The thinnest veins build an irregular network through the older quartz, whereas thicker veins are dominantly vertically oriented and trend parallel or with an angle of $30^{\circ}-40^{\circ}$ with respect to the general Pfahl trend. At several outcrops, a third phase (III), which is also white and coarse grained, transects all other quartz units as $\mathrm{cm}$ to $\mathrm{dm}$ thick, $\mathrm{N}-\mathrm{S}$ trending quartz veins (Fig. 4c). They are associated with N-S trending planar and vertical fractures dominating the outcrops at Viechtach and Weißenstein. A similar subdivision into (1) fine-grained quartz masses A and B, (2) massive white quartz and (3) late, N-S trending structures was already proposed by Yilmaz et al. (2014) after detailed structural analysis of samples from Viechtach and the Waschinger Quarry. In addition to the three phases, they described fine-grained, cataclastic quartz veins that cut the massive white quartz (2), but this might be a subordinate phase, whose occurrence is limited to the Waschinger Quarry.

Due to its different appearance (Fig. 4d) the sample from Grafenau (location 13, segment A) is described separately. In the following, the microstructural and CL characteristics of each quartz phase will be presented in detail.

\section{Fine-grained colored quartz (I)}

The colored quartz (phase I) has xenomorphic grains with irregular grain boundaries and a small grain size of $<5-50 \mu \mathrm{m}$ with individual grains up to $200 \mu \mathrm{m}$ (Fig. 5a). Numerous fine-grained granules of partly opaque accessory minerals are finely distributed between the quartz grains and lead to the colored appearance of quartz. EDX analyses of accessory minerals determined Fe-oxide, Ti-oxide, $\mathrm{Al}-$ and $\mathrm{K}-\mathrm{Al}$ silicate. This supports the presence of hematite, rutile, orthoclase, kaolinite and sericite as accessory mineral phases. Besides fine-grained accessories, phase I partially contains host rock fragments consisting mainly of kaolinite, feldspar, and quartz. Besides individual coarser grains, the fine-grained matrix of quartz phase I shows a low $C L$ intensity with $C L$ variations within the small grains (Fig. 5b). The irregular grain boundaries and small grain size allow to describe phase I as cryptocrystalline quartz. One sample from location 3 shows elongated grains of about $100 \mu \mathrm{m}$ length forming a reticulated quartz fabric (Fig. 5c). The long axes of the elongated grains are oriented parallel and perpendicular to each other and the crystal orientation is preferentially oriented parallel to the long grain axes (Fig. 5d). A similar fabric was described by Lovering (1972) and interpreted as replacement fabric during silicification of host rocks (jasperoid). 


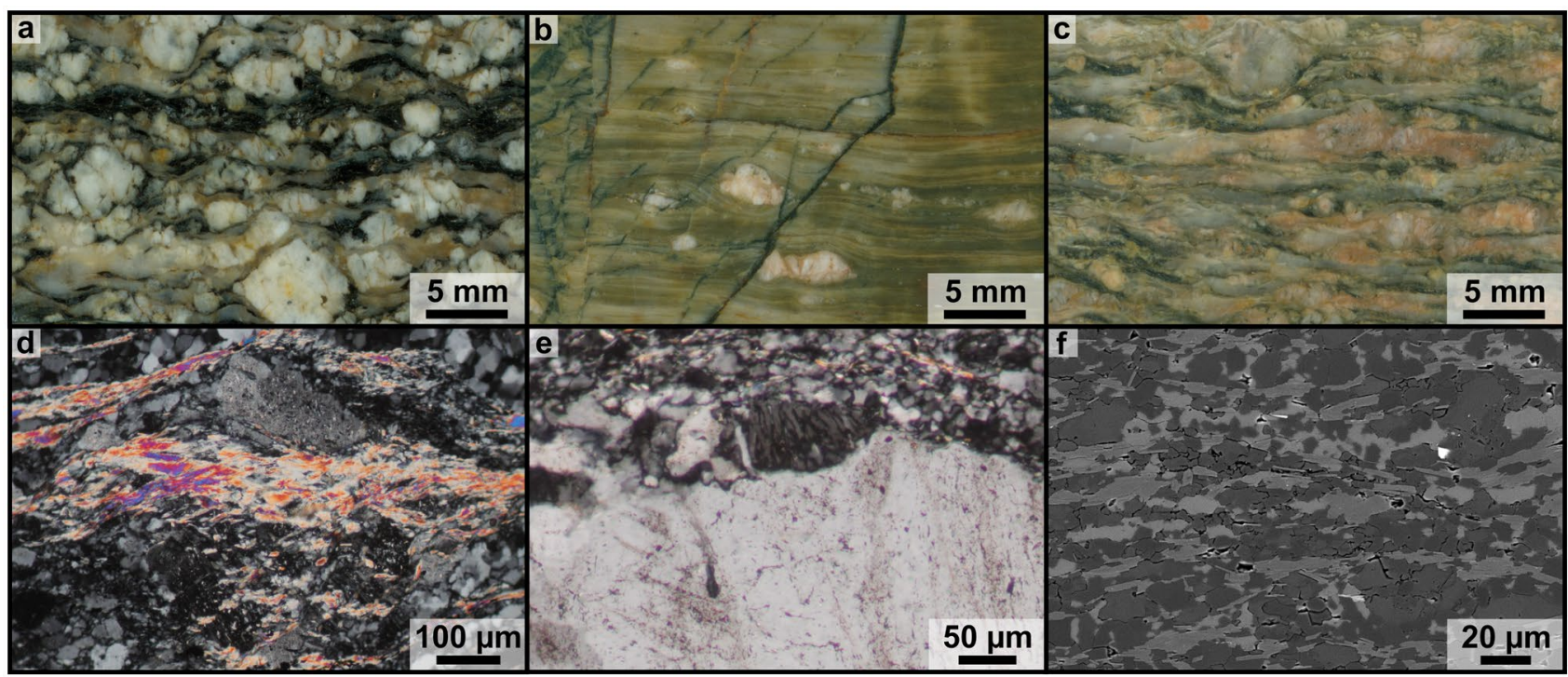

Fig. 3 Mesoscopic and microscopic structures of deformed rocks from the main Pfahl shear zone. a Mylonitic plagioclase granite (Rinchnach, segment C). b Fine-grained feldspar-quartz-muscovite-chlorite ultramylonite (Rinchnach, central part of the Pfahl shear zone). c Mylonitic kalifeldspar granite (Grafenau). d Alteration of kalifeldspar $(0-5 \% \mathrm{Na}, \mathrm{EDX})$ produced a fine-grained aggregate of sericite/muscovite and plagioclase (3-10\% Ca) (Grafenau

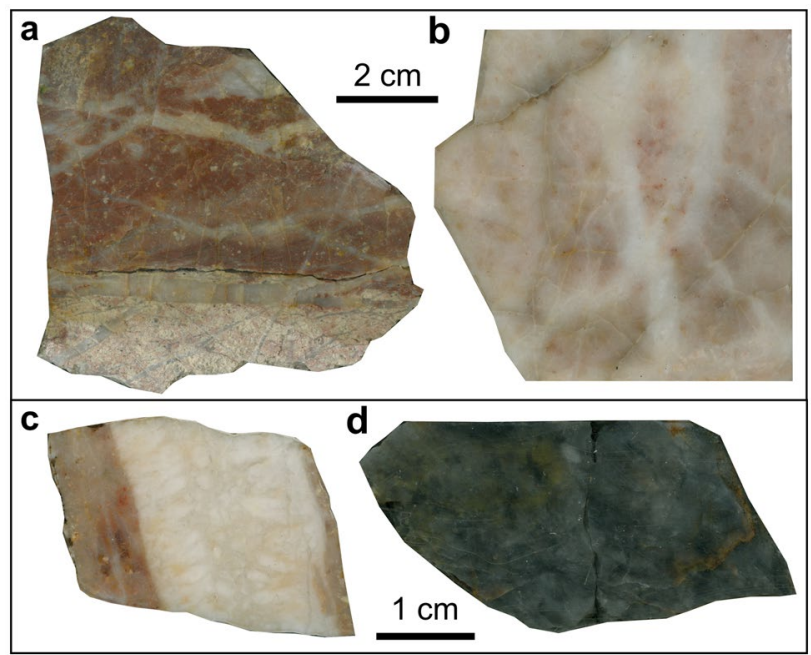

Fig. 4 Sample scans of multi-phase quartz veins. a Kaolinised host rock (lower part) and reddish quartz phase I, cut by white quartz phase II, loc. 2. b Reddish quartz phase I, cut by white quartz phase II, diffuse contacts, loc. 8. c Quartz vein of phase III with euhedral grains, loc. 8. d Black quartz from the SE edge of the Bavarian Pfahl, loc. 13

\section{Massive white quartz (II)}

In contrast to the colored quartz mass (phase I), the white quartz (phase II) has mostly straight to curved grain boundaries and a larger grain size of $20-2000 \mu \mathrm{m}$ with ultramylonite), crossed polarizers. e Stress-induced myrmekitisation (plagioclase 7.5-11.5\% Ca) of kalifeldspar (0-3.5\% Na) (Rinchnach ultramylonite), crossed polarizers. f Ultramylonite matrix developed due to previous myrmekitisation; mixture of quartz, albite $(1-7 \% \mathrm{Ca})$, oligoclase $(10-13 \% \mathrm{Ca})$, kalifeldspar $(0-3.5 \% \mathrm{Na})$, muscovite and chlorite, SEM-BSE image

individual elongated grains up to $\mathrm{cm}$ (Fig. 6a). SEM-CL analysis allows an insight into the complex internal structure of quartz phase II. Large quartz grains have a bright CL signal with several euhedral rims of variably darker CL signal (Fig. 6b, d). Zoned quartz grains were cracked by a later silica-rich fluid which formed an irregular network of mostly $<10-\mu \mathrm{m}$ - up to $100-\mu \mathrm{m}$-thick veins with dark CL intensity (Fig. 6b). Differently luminescing grains and cracks are not distinguishable under crossed polarizers because every quartz phase crystallized with the same lattice orientation as the surrounding grains (Fig. 6c). The described quartz mass is cut by another quartz subphase, visible due to a higher fluid inclusion density and a different CL signal compared to the main mineralization of phase II (Fig. 6d). The 50-400 $\mu \mathrm{m}$ thick veins show internal CL structures and surrounding quartz grains show offsets of 50-1500 $\mu \mathrm{m}$. The cracks were sealed partly by overgrowth of the transected grains, partly by mineralization of small quartz grains with random lattice orientation (Fig. 6c).

All veins of quartz phase II contain open druses of $100-1200 \mu \mathrm{m}$ in size, which are surrounded by euhedral quartz grains (Fig. 6e, f). Some veins exhibit significant amounts of accessory minerals. 10-500- $\mu \mathrm{m}$-sized grains of hematite and kaolinite are situated in druses and around euhedral quartz grains, which indicates a late precipitation of these minerals after quartz. One sample from location 2 shows accumulations of fine-grained quartz mixed with accessory minerals (kaolinite, orthoclase, hematite), 
Fig. 5 Detailed view of phase I at loc. $8(\mathbf{a}, \mathbf{b})$ and at loc. $3(\mathbf{c}$, d). a Cryptocrystalline quartz with irregular grain boundaries, crossed polarizers. b SEM-CL image of the section in a. c Reticulated quartz fabric with parallel and perpendicular-oriented long grain axes, crossed polarizers. d Same section like c with $\lambda / 4$ plate. The crystal axes are oriented parallel to the long grain axes

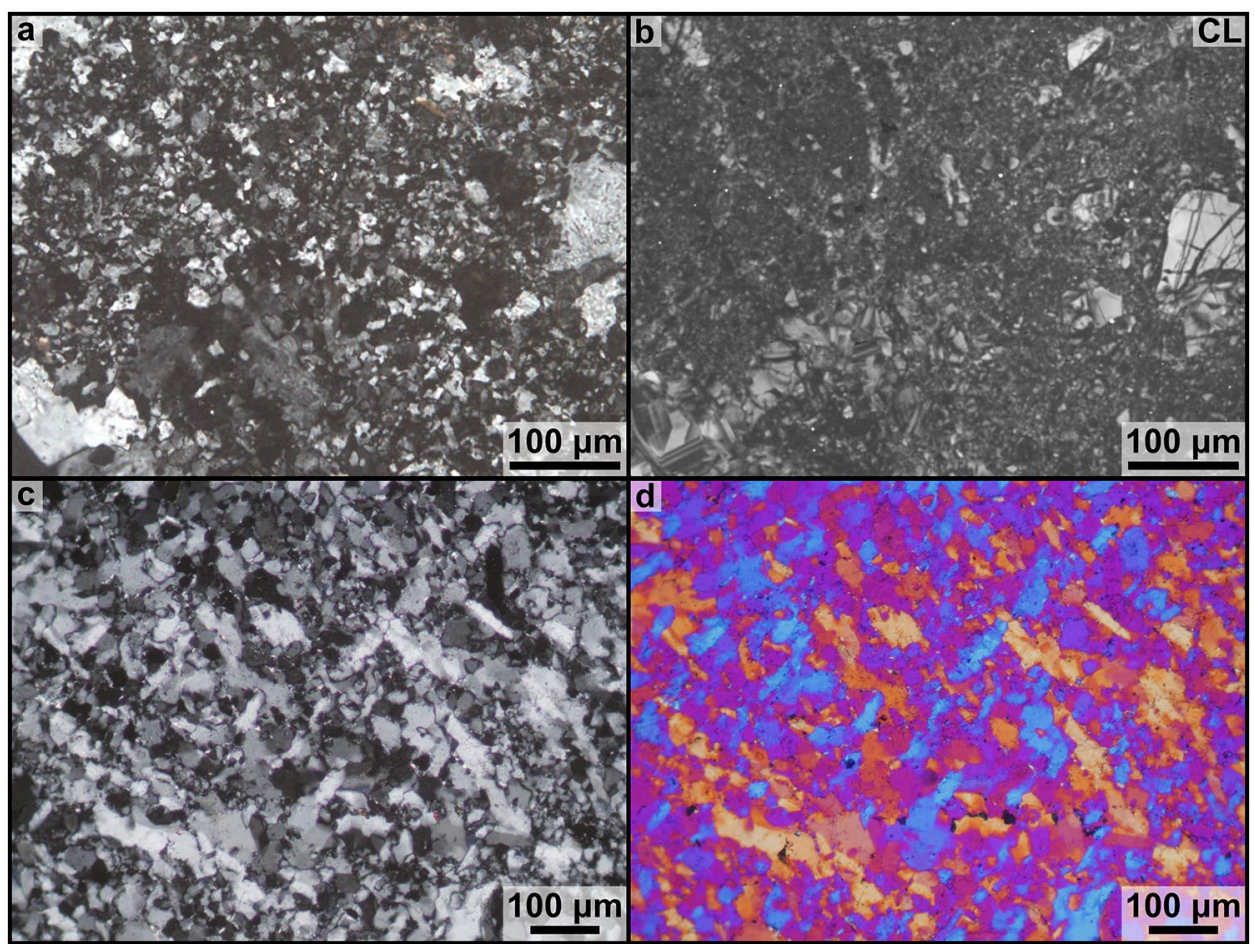

building a sutured structure along grain boundaries. The position around euhedral quartz grains indicates that it represents the late precipitate of the remaining fluid after closure of the quartz vein. More fine-grained quartz with hematite and kaolinite is detected along straight linear structures, socalled crack and seal fabric (Ramsay 1980).

Phase II generally shows few fluid inclusions, with the exception of accumulations of fluid inclusions around druses and grain boundaries. The fluid influence around druses generates a dark CL signal in the surrounding quartz grains (Fig. 6f). These fluid-inclusion-rich areas are overgrown by fluid-inclusion-free quartz.

\section{North-south trending quartz veins (III)}

The veins of quartz phase III consist mainly of blocky to elongated, partly euhedral grains of 50-7000 $\mu \mathrm{m}$ size. Phase III shows a highly variable fluid-inclusion density. CL images together with polarized light microscopy observations visualize the complex internal structure of quartz phase III (Fig. 7). Initially grown grains with bright CL signal were overprinted by fracturing, marked by a dark CL fracture network and a high fluid-inclusion density affecting the grain cores. The grain rims are fluid-inclusion-free and show zoning of CL intensity (Fig. 7a, b). Euhedral grain growth is followed by precipitation of fine-grained $<5-50-\mu \mathrm{m}$-sized quartz, filling the gaps between the blocky grains (Fig. 7c, d). In some areas, crystal growth and formation of cryptocrystalline quartz alternate multiple times (Fig. 7c, d). All described subphases are cut by around 100- $\mu$ m-thick fluidinclusion-free quartz veins, which show internal CL structuring. The veins show sporadic offsets of about $50 \mu \mathrm{m}$ and are sealed by overgrowth of the surrounding quartz grains (Fig. 7c, d). In general, late subphases of a fluid batch, represented by grain rims or fracture networks, seem to precipitate quartz with dark CL signal. The macroscopic white color and the lack of distinguishable accessory phases in quartz phase III suggest pure quartz precipitation without accessory minerals. Individual blocky grains show patchy undulose extinction indicating a large number of lattice defects.

\section{Transition to segment A}

In contrast to other quartz samples from segment $\mathrm{B}$, which in general do not show deformation microstructures, the Weißenstein sample is characterized by brittle deformation microstructures (Fig. 8a-d). Healed microcracks and probably cemented aggregates of crushed fine-grained particles build a heterogeneous microstructure with orientation domains of different size and misorientation relationship (Fig. 8c). These brittle deformation microstructures only occur in the relatively coarse-grained quartz I aggregates, which are characterized by a high content of impurities (solid phases and fluid inclusions at $\mu \mathrm{m}$ scale). Ductile microstructures as identified in the Grafenau sample of segment A (see below) are not evident. Quartz II crosscuts quartz I and the fine-grained kaolinite matrix. In plane light, 
Fig. 6 Detailed view of phase II at loc. 8 (a-d) and at loc. 2

(e, f). a Large, partly euhedral quartz grains with straight boundaries, crossed polarizers. b SEM-CL image of the section in a showing varying CL-intensities within the grains. c Sealed veinlet cutting a quartz grain, crossed polarizers. d SEM-CL image of the section in c, showing zoning of large quartz grain and internal CL pattern of veinlet. e Large quartz grain with fluid-inclusion-rich areas and euhedral grain shape towards open druse, parallel polarizers. f SEM-CL image of the section in $\mathbf{e}$, showing a dark CL signal in fluid-inclusion-rich areas

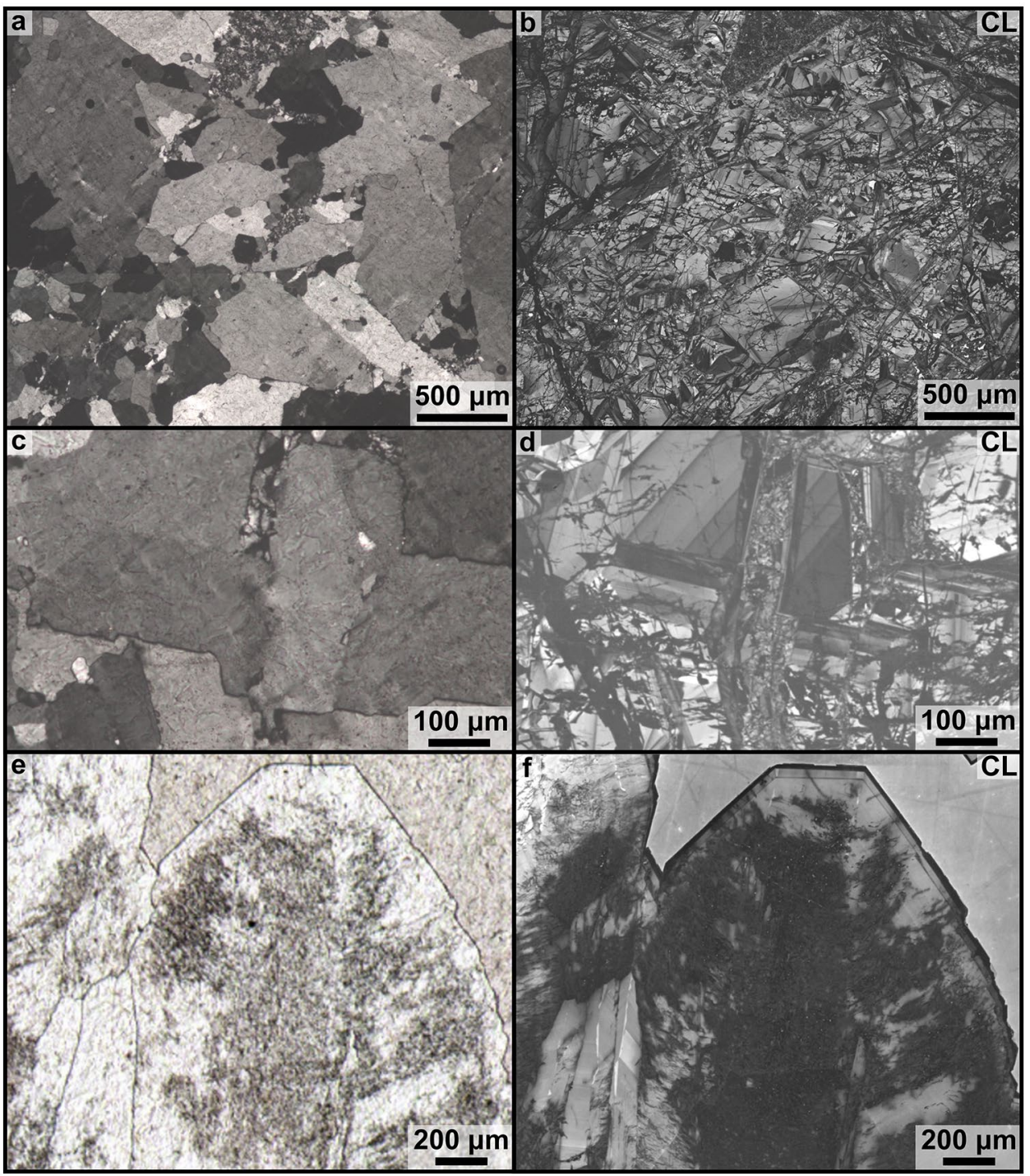

quartz II shows only few impurities and appears relatively clean compared to quartz I (Fig. 8b, d). In general, quartz II veins do not show deformation microstructures, neither ductile nor brittle ones.

The Grafenau sample (location 13) has a different appearance as compared to the other localities. Here the quartz is almost black with lighter cloudy parts (Fig. 4d). Grain sizes vary from several $\mathrm{mm}$ to $10 \mu \mathrm{m}$ and the microstructure is very heterogeneous. Due to the partly small grain size and the intense coloring, the Grafenau sample can be referred to quartz phase I. In contrast to samples from segments B and $\mathrm{C}$, the mm-sized grains reveal various deformation features (Fig. 8f-h) including (1) patchy undulose extinction; (2) deformation lamellae; (3) deformation bands; (4) localized extinction bands and (5) inter- and intracrystalline bands of new small recrystallized grains. Deformation lamellae are frequently overprinted by crystal plastic processes and, therefore, appear as subparallel extinction bands (Fig. 8f, g).
Intersections of differently orientated extinction bands and intracrystalline shear bands cause an internal mosaic of elongated subdomains at various sizes within the coarse quartz grains. Grain boundaries are highly serrate and frequently show bulges with sizes of 5-10 $\mu \mathrm{m}$ (both in amplitude and wavelength). The finer grained parts of the veins contain grains with various size, mostly in the range of 50-200 $\mu \mathrm{m}$ and serrate grain boundaries (Fig. $8 \mathrm{~h}$ ). Grain transitions are defined by subgrains or small new grains $(5-10 \mu \mathrm{m})$.

\section{Geochemical results}

\section{Trace elements}

Trace element contents of Bavarian Pfahl quartz vary by several orders of magnitude, for example, $\mathrm{Zr}$ contents range from 0.02 to $9 \mathrm{ppm}$ and Ba from 0.2 to $218 \mathrm{ppm}$ (Table 1; 
Fig. 7 Detailed view of phase III at loc. $8 . \mathbf{a}+\mathbf{b}, \mathbf{c}+\mathbf{d}$ The same sections, respectively. a, c crossed polarizers. b, d SEM$\mathrm{CL}$ images. a, b Euhedral quartz grains with fluid-inclusion-rich core and fluid-inclusion-free overgrowth overprinted by irregular fracturing and sealing. c, d Alternating euhedral grain growth and precipitation of cryptocrystalline quartz, overprinted by veinlets creating small offsets

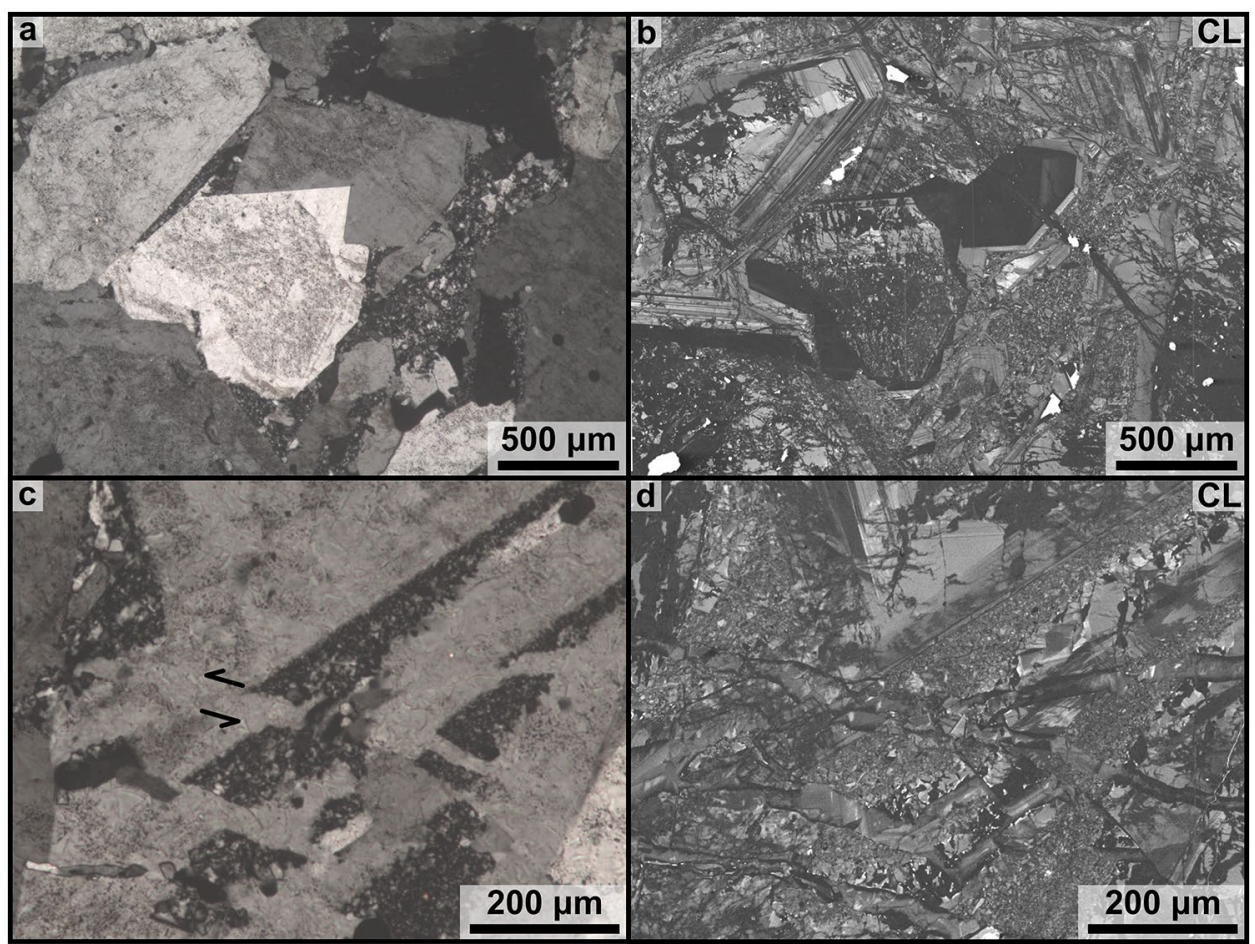

Fig. 9). The structurally defined multi-phase mineralization of the Bavarian Pfahl quartz is confirmed by the trace element signature of quartz. The colored quartz (phase I) has generally higher trace element concentrations compared to the white quartz (phases II and III). This variation is most distinct in $\mathrm{Ti}, \mathrm{Zr}, \mathrm{Sc}$ and the light rare earth elements (LREE) (Fig. 9a, b). Lithium behaves differently showing higher contents in phase II compared to phase I (Fig. 9c). Some elements such as $\mathrm{Sr}, \mathrm{Pb}$ and $\mathrm{Ag}$ do not differ between the phases (Figs. 9e, 10d). The different colors of samples of phase I cannot be matched to geochemical differences. The N-S trending quartz phase III, which is represented by three samples, has element contents that are in the range of phase II for all elements. Element concentrations plotted against the lateral extension of the Bavarian Pfahl quartz lode (Fig. 10a-d) show decreasing maximum concentrations from $\mathrm{NW}$ to $\mathrm{SE}$ for the large ion lithophile elements (LILE, $\mathrm{Rb}, \mathrm{Sr}, \mathrm{Cs}, \mathrm{Ba}$ ), for some transition metals ( $\mathrm{Sc}, \mathrm{V}, \mathrm{Ni}$, $\mathrm{Cu}, \mathrm{Zn}$ ) and for $\mathrm{Li}$ and $\mathrm{Pb}$. The high-field-strength elements (HFSE) and the rare earth elements (REE) do not show significant regional trends.

Linear correlations of two elements (Fig. 9) can be observed within the HFSE between $\mathrm{Ti}, \mathrm{Zr}, \mathrm{Nb}, \mathrm{Ta}, \mathrm{Hf}$, U and Th. There is a moderate correlation between the remaining transition metals $\mathrm{Sc}, \mathrm{V}, \mathrm{Cr}, \mathrm{Co}, \mathrm{Ni}, \mathrm{Cu}$ and $\mathrm{Zn}$. Additional data of Peucker-Ehrenbrink and Behr (1993) show strong correlations between $\mathrm{Zn}, \mathrm{Fe}, \mathrm{Mn}, \mathrm{Cr}$ and $\mathrm{Co}$. The LILE Rb, $\mathrm{Sr}, \mathrm{Cs}$ and $\mathrm{Ba}$ do not correspond besides weak correlations of $\mathrm{Rb}$ with $\mathrm{Cs}$ and $\mathrm{Sr}$ with $\mathrm{Ba}$ (Fig. 9e).
REE contents are normalized to post-Archean average Australian shale (PAAS, Taylor and McLennan 1985) and plotted in Fig. 11. All quartz samples show flat PAAS-normalized patterns from $\mathrm{La}$ to $\mathrm{Sm}$. Concentrations of $\mathrm{Eu}-\mathrm{Lu}$ are below the detection limit for most of the samples. Several samples of phase I show negative $\mathrm{Ce}$ anomalies and three samples show a slightly negative Eu anomaly. Total REE contents lie between 1 and $30 \mathrm{ppm}$ for phase I and below $1 \mathrm{ppm}$ for phases II and III.

The quartz from Wölsendorf shows slightly different trace element patterns from the Bavarian Pfahl quartz (Figs. 9, 10). Two Wölsendorf quartz samples have $U$ contents of 3.7 and $7.4 \mathrm{ppm}$ which is by a factor of 10 higher than in the Bavarian Pfahl quartz (Fig. 9d). A brownish quartz sample, containing hematite, has significantly higher concentrations of $\mathrm{Co}, \mathrm{Ni}, \mathrm{Cu}, \mathrm{Zn}, \mathrm{V}$ and $\mathrm{Pb}$ (Fig. 10d) but contains no HFSE. White and pure quartz samples from Wölsendorf have lower transition metal, but high $\mathrm{Li}, \mathrm{Sr}$ and $\mathrm{Cs}$ concentrations (Fig. 9c, e). One sample contains LREE and shows a slightly different distribution compared to the Pfahl quartz with a similar $\mathrm{La} / \mathrm{Ce}$ ratio, a lower $\mathrm{La} / \mathrm{Sm}$ ratio and a stronger negative Eu anomaly (Fig. 11). The Wölsendorf quartz precipitated next to blue fluorite, which represents the primary fluorite mineralization event of the fluorite-barite deposit. Fluorites from Wölsendorf have been analyzed in detail by Dill and co-authors (Dill and Weber 2010; Dill et al. 2011, 2012) who showed a relationship between the REE composition and the color of fluorite. The REE patterns of quartz and blue fluorite from Wölsendorf resemble 
Fig. 8 Optical microstructure of quartz from Weißenstein (loc.

12 , transition of segments A and B) and from Grafenau (loc. 13, segment A). Weißenstein. a Heterogeneous microstructure of coarse-grained quartz (qtz I, qtz II) and fine-grained kaolinite (kln), crossed polarizers. b, d Cross-relationship of deformed coarse quartz I (with many inclusions) and non-deformed quartz II (few inclusions). b Crossed polarizers and inlay of same area with plain light. c, $\mathbf{d}$ Details of quartz I and quartz II microstructure (same area imaged with $\mathbf{c}$ crossed polarizers and $\mathbf{d}$ plain light). Note in $\mathbf{c}$ brittle deformation microstructure of quartz I and non-deformed microstructure of quartz II. Grafenau. All micrographs are taken with crossed polarizers. e Heterogeneous microstructure of coarse-grained and fine-grained quartz. f Deformation lamellae in coarse quartz grain. $\mathbf{g}$ The coarse grains show lower greenschist intracrystalline deformation microstructures, i.e., patchy undulose extinction; localized extinction bands and overprinted deformation lamellae. Coarse quartz grains in the upper part show inter- and intracrystalline patches of subgrains (black arrows). h Characteristic deformation microstructure of fine-grained part of the quartz vein, mainly dominated by bulging recrystallization. Patches of subgrain mosaic indicates also subgrain rotation

\section{Weißenstein (location 12, segment B) Grafenau (location 13, segment A)}

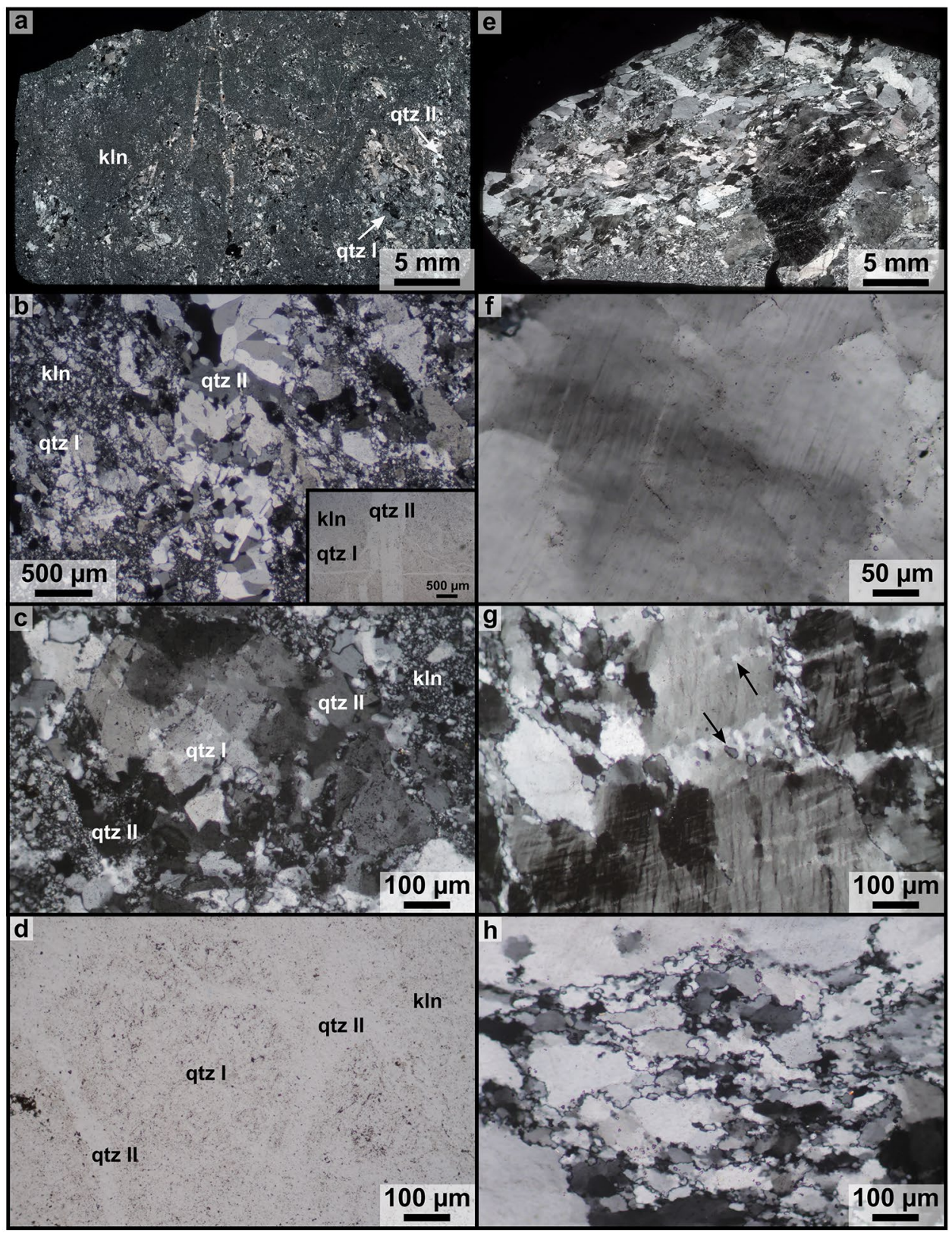

each other with a negative $\mathrm{Ce}$ anomaly and a negative $\mathrm{Eu}$ anomaly (Fig. 11).

\section{Oxygen isotopes}

The $\delta^{18} \mathrm{O}$ of Bavarian Pfahl quartz ranges from 7.77 to $13.48 \%$ with a regional decrease from NW to SE in segments B and C and a plateau in segment A (Fig. 12; Table 1). Three quartz samples from Wölsendorf which mineralized next to fluorite have higher $\delta^{18} \mathrm{O}$ values of 15.87-18.45\%o, marking the northwestern maximum of the regional trend. The different quartz phases I, II and III of the Bavarian Pfahl quartz cannot be distinguished by their $\delta^{18} \mathrm{O}$. The oxygen isotope fractionation between quartz and water depends on the temperature during mineralization. Temperature estimations allow to calculate $\delta^{18} \mathrm{O}$ values of the hydrothermal fluid using quartz-water fractionation after Clayton et al. (1972) (Table 2). The regional trend of $\delta^{18} \mathrm{O}$ along the Bavarian Pfahl can be explained by different fluid compositions (i, ii), which are shown in Fig. 12 and will be discussed later. 

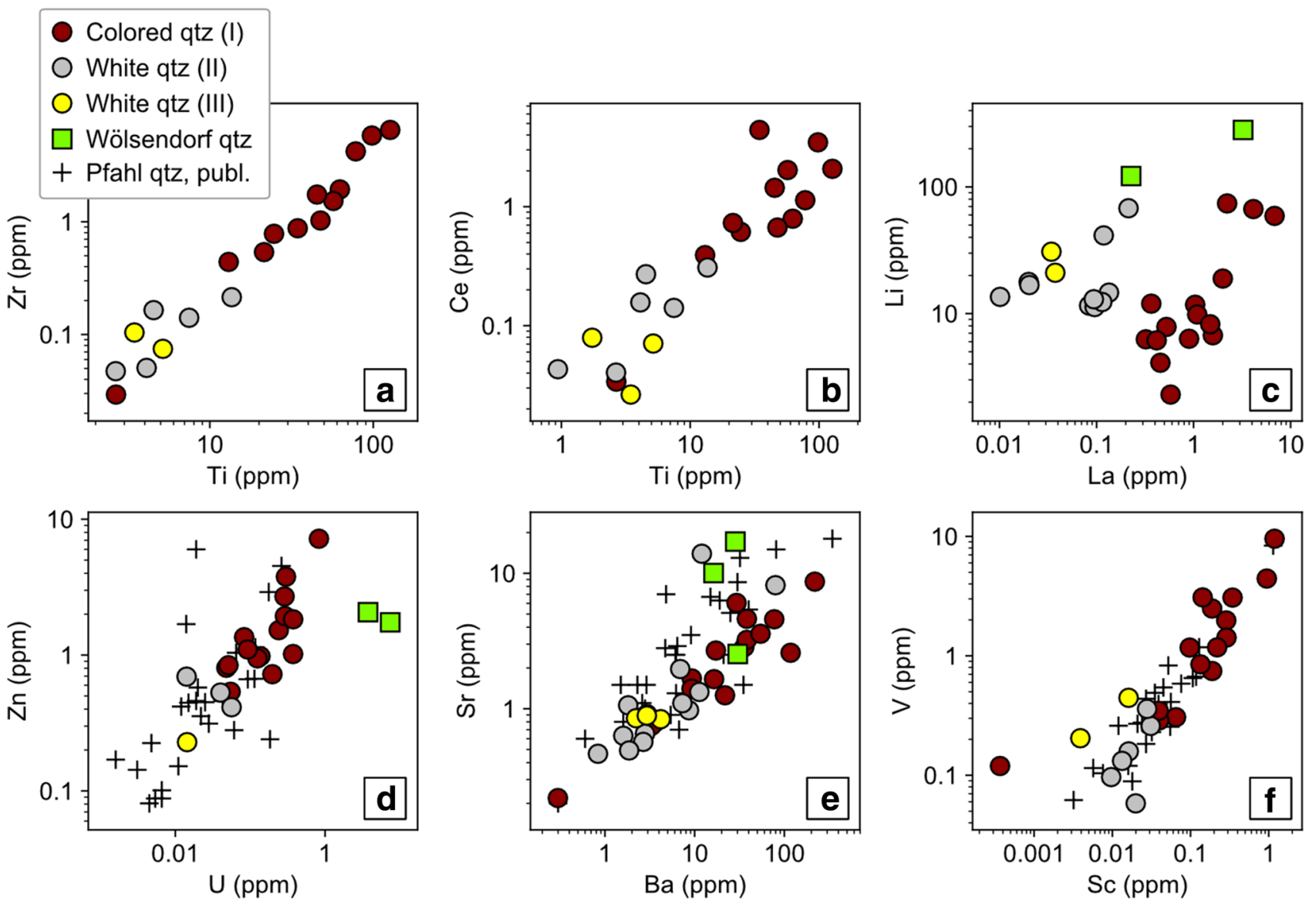

Fig. 9 Element correlations in quartz from the Pfahl and from Wölsendorf. Published data are from Peucker-Ehrenbrink and Behr (1993). Both axes are scaled logarithmically. Phase I frequently has

\section{Discussion}

\section{Chemical distinction of multiple quartz phases}

Trace element contents of quartz are generally low due to the rare substitution of $\mathrm{Si}^{4+}$ by few other elements such as $\mathrm{Al}^{3+}, \mathrm{Fe}^{3+}$ or $\mathrm{Ti}^{4+}$. The trace element contents of our quartz samples, therefore, represent the compositions of fluid inclusions and solid micro-impurities as proposed previously for the Bavarian Pfahl quartz by Peucker-Ehrenbrink and Behr (1993). According to Gerler (1990), the proportions of element contents in Bavarian Pfahl quartz stored in fluid inclusions lie below $15 \%$ for most elements that were determined in this study. Hence, accessory mineral phases remain the main host for trace elements in Bavarian Pfahl quartz. Linear correlations of trace elements in quartz (Fig. 9) may be caused by mixing of two minerals, one with high contents and one with low contents and, therefore, support the occurrence of accessory minerals. However, we suggest that the trace element content of quartz closely reflects the composition of the higher element contents than phases II and III. Wölsendorf shows high $\mathrm{Li}, \mathrm{U}$ and $\mathrm{Sr}$ contents

fluids leading to the precipitation of the different minerals and the formation of inclusions.

The macroscopic distinction of three major quartz phases due to color, grain size and vein orientation was confirmed by microstructural and geochemical analysis. High trace element concentrations and the color of quartz phase I relative to white quartz of phases II and III (Fig. 9) are expected to originate from finely distributed accessory minerals. Iron concentrations of about 100 ppm (Peucker-Ehrenbrink and Behr 1993) and EDX analysis of this study indicate the presence of Fe-oxides such as hematite, which also explains the reddish color of numerous samples of phase I. Elevated transition metal concentrations are caused by substitution of $\mathrm{Fe}$ in $\mathrm{Fe}$-oxides. Titanium concentrations up to $100 \mathrm{ppm}$ in phase I (Fig. 9a) suggest the presence of a Ti-phase like rutile, which can incorporate significant amounts of HFSE, particularly $\mathrm{Zr}, \mathrm{Hf}, \mathrm{Nb}$, Ta, but also $\mathrm{V}, \mathrm{Cr}$ and Sn (Zack et al. 2002; Klemme et al. 2005). This is supported by high HFSE contents and their correlation with Ti (Fig. 9a, b). Zirconium contents of 1-9 ppm in the 
Fig. 10 Trace element contents of quartz plotted against the lateral distance along the Bavarian Pfahl. Published data are from Peucker-Ehrenbrink and Behr (1993). Maximum element contents decrease from NW to SE
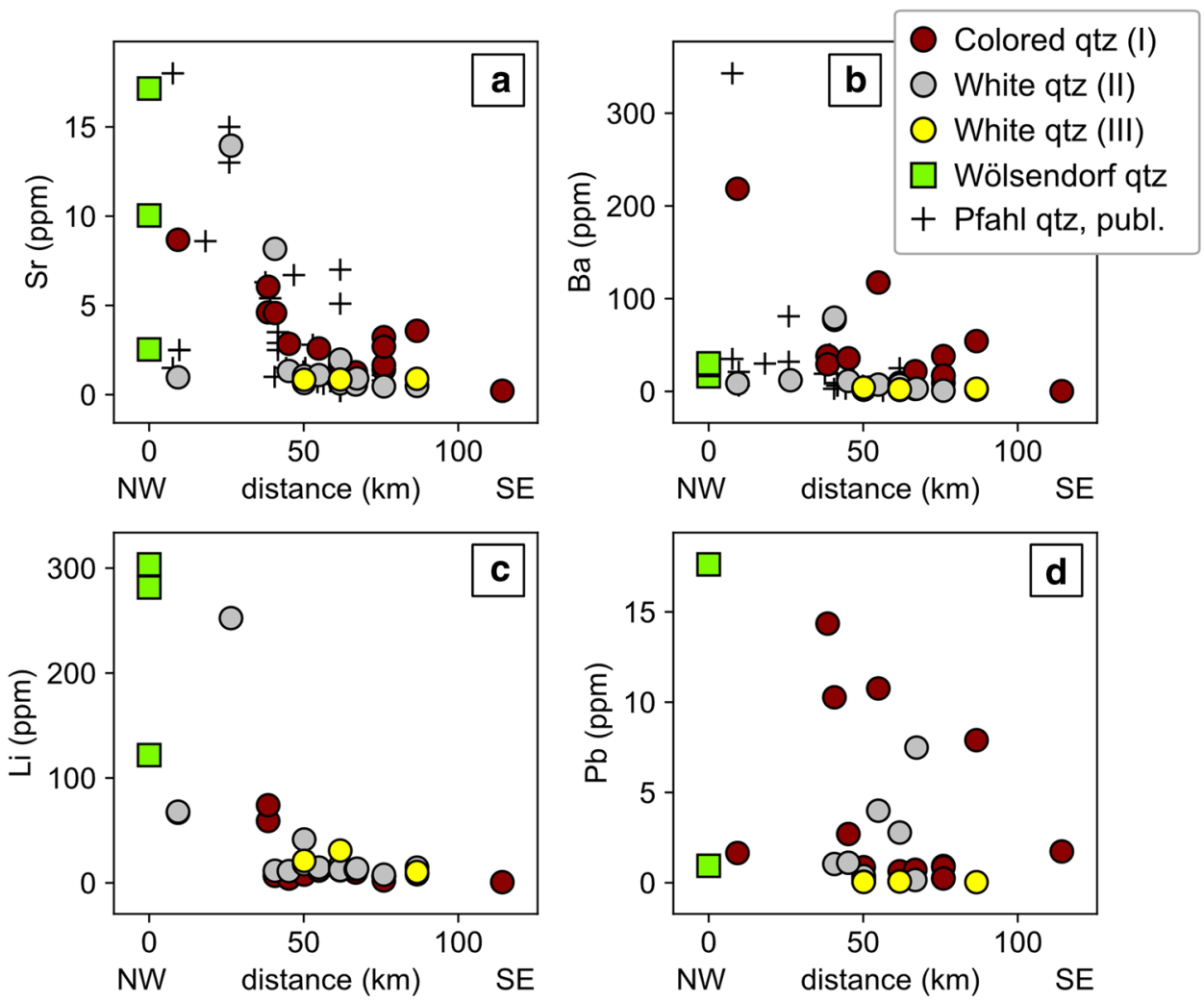

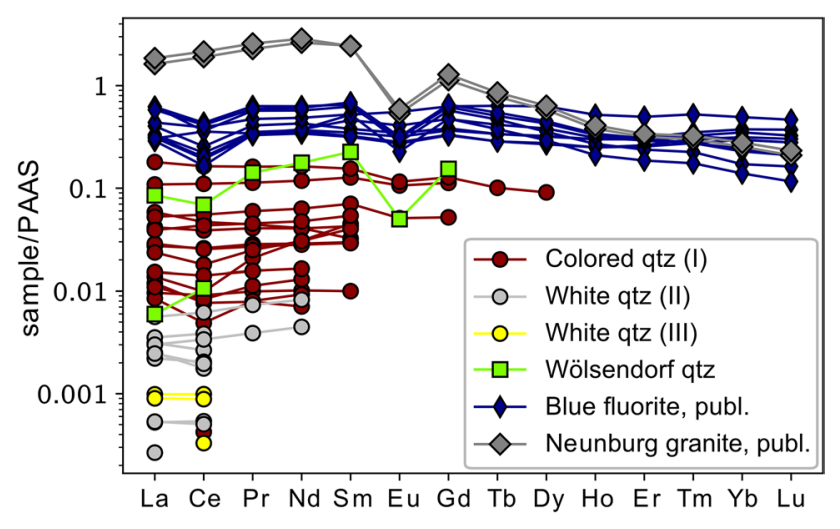

Fig. 11 REE distribution of Bavarian Pfahl quartz, Wölsendorf quartz, blue fluorite from Wölsendorf (data from Dill et al. 2011) and Neunburg granite (data from Chen et al. 2003), which hosts the Wölsendorf fluorite deposit. Element concentrations are shale normalized (PAAS post-Archean average Australian shale, Taylor and McLennan 1985). The vertical axis is scaled logarithmically

absence of Ti in quartz phase I from the NW Pfahl section (segment $\mathrm{C}$ ) indicate the presence of zircon as accessory mineral. Hydrothermal zircon is enriched in HFSE including U, Th and REE (Hoskin 2005). Peucker-Ehrenbrink and Behr (1993) interpreted high Al concentrations up to 1.2 wt.\% and the correlation of $\mathrm{Al}$ with $\mathrm{Cs}, \mathrm{Rb}, \mathrm{Na}$, $\mathrm{K}$ and $\mathrm{Ti}$ as an indicator for the presence of Al-phases such as mica and feldspar. This is in accordance with

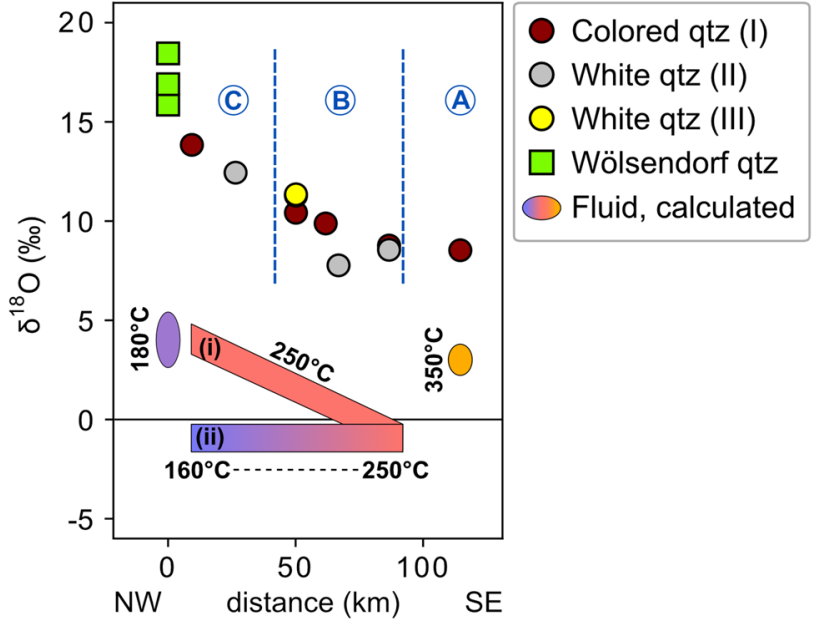

Fig. 12 Regional decrease of $\delta^{18} \mathrm{O}_{\mathrm{qtz}}$ along the Bavarian Pfahl from $\mathrm{NW}$ to SE. The related $\delta^{18} \mathrm{O}_{\text {fluid }}$ are calculated by quartz-water fractionation after Clayton et al. (1972) with estimated mineralization temperatures inferred from quartz microstructures. Two possible scenarios (i and ii) for fluid compositions and mineralization temperatures of quartz are discussed in the text

high $\mathrm{Rb}$ and $\mathrm{Cs}$ contents, as well as kaolinite, sericite and feldspar in phase I. Lithium is the only element that shows predominantly higher contents in phases II and III compared to phase I (Fig. 9c). In crustal rocks, $\mathrm{Li}$ is dominantly hosted by clay minerals such as kaolinite which, 
Table $2 \delta^{18} \mathrm{O}_{\mathrm{qtz}}$ ranges of Wölsendorf and Bavarian Pfahl quartz and calculated $\delta^{18} \mathrm{O}_{\text {fluid }}$ for estimated mineralization temperatures and quartz-water fractionation after Clayton et al. (1972)

\begin{tabular}{llll}
\hline Location & $\delta^{18} \mathrm{O}_{\mathrm{qtz}}(\% \circ)$ & $\mathrm{T}\left({ }^{\circ} \mathrm{C}\right)$ & $\delta^{18} \mathrm{O}_{\text {fluid }}(\% \circ)$ \\
\hline Wölsendorf & 15.87 to 18.45 & $180^{\mathrm{a}}$ & 2.67 to 5.22 \\
Bavarian Pfahl, loc. 1 & 13.84 & 160 to 250 & -0.88 to 4.80 \\
Bavarian Pfahl, loc. 12 & 8.65 & 160 to 250 & -6.10 to -0.47 \\
Bavarian Pfahl, loc. 13 & 8.52 & 300 to 350 & 1.59 to 3.18 \\
\hline
\end{tabular}

${ }^{\text {a} D}$ Dill et al. (2012)

for example, contains up to $120 \mathrm{ppm} \mathrm{Li} \mathrm{(Horstman} \mathrm{1957).}$ After this, accessory kaolinite cannot explain Li contents of 2-80 ppm measured in quartz. Substitution of $\mathrm{Si}^{4+}$ by $\mathrm{Al}^{3+}$ in quartz is coupled with a charge balance by additional incorporation of $\mathrm{H}^{+}, \mathrm{Li}^{+}, \mathrm{Na}^{+}$and $\mathrm{K}^{+}$. Götze et al. (2004) and Jourdan et al. (2009) report Li concentrations of $>150 \mathrm{ppm}$ incorporated in the quartz lattice of pegmatite quartz and vein quartz. Therefore, quartz of phases II and III incorporated Li during crystal growth, due to enriched $\mathrm{Li}$ concentrations in the hydrothermal fluid.

To summarize the results of structural and geochemical analyses complemented by data from Peucker-Ehrenbrink and Behr (1993), the fine-grained quartz phase I contains accessory hematite, kaolinite, feldspar, sericite, rutile and zircon, whereas phases II and III contain less or no accessory minerals but incorporate more Li.

\section{Quartz formation}

The quartz shows large variations in grain size, grain shape and growth interaction of crystals, which can be interpreted in terms of variations in crystallization processes during Pfahl quartz formation.

The fine-grained quartz fabric with irregular grain shapes in phase I (Fig. 5) points towards a crystallization of quartz from a former colloidal silica gel, as it was observed along fault zones and in epithermal vein systems (Herrington and Wilkinson 1993; Simmons et al. 2005). A silica gel can be formed under low-temperature and -pressure conditions from a silica-supersaturated fluid. Increasing temperatures or pressures during ongoing brittle deformation promote the conversion from amorphous silica into crystalline quartz (Lovering 1972). During the first hydrothermal event (phase I), fluid-rock interaction led to infiltration and silicification of the strongly altered granites and gneisses in segments B and C. Fragments as well as single grains of the host rocks were transported by the ascending silica-saturated fluid (Fig. 13a, b). This led to the fine distribution of accessory minerals such as kaolinite, feldspar and sericite within phase I. Iron-enrichment of the hydrothermal fluid is responsible for finely distributed hematite, which precipitated during solidification of the silica gel.

Some characteristics of phase I closely resemble the characteristics of a jasperoid (Lovering 1972): (1) fine-grained, cryptocrystalline quartz, derived from silica gel (Fig. 5a), (2) gray to reddish color due to finely distributed hematite
Fig. 13 Details of quartz microstructure. a, c Sample scan. b, d Detailed view, crossed polarizers. a, b Reddish cryptocrystalline quartz (phase I) with irregular grain boundaries has overprinted the hosting granitoid at loc. 4. Kaolinized fragments of the granitic host rock (GR) and quartz veins of phase II are visible on specimen scale. c, d Cryptocrystalline quartz results from colloidal silica gel which fills the vugs between large euhedral quartz grains within phase III, loc. 9

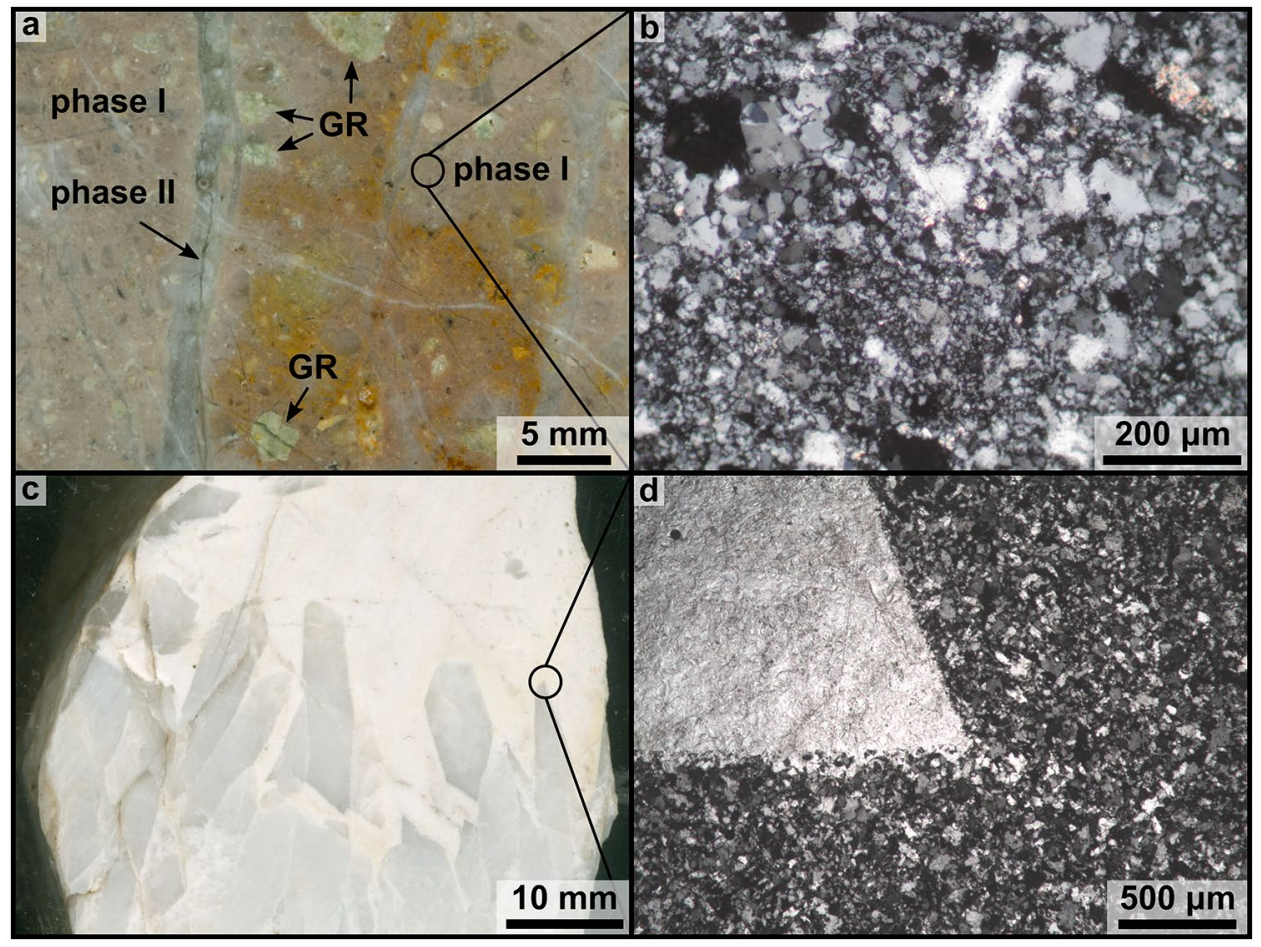


and other accessories, (3) occurrence along a shear zone, (4) reticulated quartz fabric (Fig. 5c). Jasperoids are rocks, composed dominantly of fine-grained quartz, that typically form by replacement of carbonates along fault zones, but there are also representative examples within plutonic host rocks (Ibrahim et al. 2005; El-Naby 2008). Phase I is the product of a strong interaction between kaolinised host rocks and an ascending, Fe-rich, silica supersaturated hydrothermal fluid along the preexisting Pfahl shear zone.

The existing quartz lode of phase I was used as preferred pathway for subsequent fluid flow, which reduces the contact between fluid and host rock. The ascending silica-rich fluid fractures the existing quartz lode and precipitates pure quartz veins by growth of large and partly euhedral grains (Figs. 6,7). Accessory minerals situated in druses indicate late precipitation of dissolved elements that could not be incorporated into the quartz lattice. Low trace element concentrations of quartz phase II (Fig. 9) are explained by the sample selection from macroscopically pure and white quartz, avoiding druses with accumulations of accessory minerals. The internal structure of quartz with an irregular fracture network indicates repeated fragmentation and precipitation within phase II.

The late N-S trending quartz veins (phase III) that occur between Cham and Regen (segment B) show similar internal structures and geochemical compositions like phase II. The lack of accessory minerals in phase III indicates less enriched fluid compositions relative to the fluid of phase II. The blocky and euhedral grains (Fig. 7a) must have crystallized in open fractures, which indicates fault-dilation during precipitation of phase III. This is supported by the vein orientation, trending parallel and opening perpendicular to the N-S trending main stress axes. The cryptocrystalline subphases formed by conversion of a colloidal silica gel into quartz. The silica gel filled up druses and open spaces between large euhedral quartz grains (Fig. 13c, d). Alternating crystal growth and accumulation of cryptocrystalline quartz (Fig. 7c) point towards alternating hydrothermal conditions. While crystal growth can occur under higher temperatures and pressures, silica gel can only form under low-temperature conditions from a supersaturated fluid in open spaces.

The intensity of the CL signal, which primarily depends on the chemical composition of quartz, varies strongly within Bavarian Pfahl quartz (Figs. 6, 7). Element concentrations of $\mathrm{Ti}, \mathrm{Al}, \mathrm{Li}, \mathrm{K}, \mathrm{Fe}$ in quartz are well known to show correlations with the CL intensity (Landtwing and Pettke 2005; Rusk et al. 2008). The trace element content of quartz again can depend on (1) the fluid chemistry and fluid pH (Rusk et al. 2008), (2) the temperature (e.g., Wark and Watson 2006) and (3) the quartz growth rate (Ihinger and Zink 2000; Landtwing and Pettke 2005), for example, the higher the temperature and the growth rate, the more trace elements are incorporated into quartz. Furthermore, intrinsic defects, such as dislocations, poor ordering, or included $\mathrm{H}_{2} \mathrm{O}$ can also cause low CL intensity (Marshall and Mariano 1988). CL oscillation patterns and zoning within quartz may, therefore, be related to variations of these parameters. Frequently observed dark CL signal in late fractures and late overgrowths (e.g., Fig. 7b) indicates decreasing trace element contents during one precipitation episode. High fluid-inclusion density in the different quartz phases inhibits high CL intensities (Fig. 6e, f). Fluid inclusions seem to be trapped (1) during sealing of fracture networks, (2) during late precipitation of quartz and accessory minerals and (3) during secondary fluid infiltration events.

\section{Temperature conditions}

The fluid-inclusion study on Pfahl quartz by Oppermann (1990) and Peucker-Ehrenbrink and Behr (1993) suggests mineralization temperatures in the range of $120-280{ }^{\circ} \mathrm{C}$ for segment B. For segment A, no information is available from microthermometry, so microstructural information will be considered for an estimate of temperature conditions. We are aware that deformation features such as microstructures of quartz cannot be used strictly as a thermometer since having a dependence on strain rates, stress, water content and other parameters (Handy et al. 2007 and references therein). However, microstructural observations can give a hint on quartz deformation temperature as temperature is a crucial parameter for activation of crystal-plastic deformation.

To estimate temperatures during quartz deformation in segment A, we applied the categorizing scheme of Derez et al. (2015) for intracrystalline deformation in the range of $270-400{ }^{\circ} \mathrm{C}$. Undulose extinction, deformation bands, localized extinction bands, subgrain development and new recrystallized grains (Fig. 8e-h) form sequentially by crystal plastic processes with increasing strain (e.g., White 1976, 1977). The similar size of subgrains and new recrystallized grains of inter- and intracrystalline localized shear bands (Fig. 8g) in combination with undulose extinction gives evidence of crystal-plastic slip with recovery and dynamic recrystallization by subgrain rotation (Urai et al. 1986). Besides these features, deformation microstructure in the Grafenau sample is dominated by bulging recrystallization indicated by the transition from highly serrate grain boundaries towards new grains in the same size as the bulges (Fig. 8h). Stipp et al. (2002) classify the deformation temperatures of quartz microstructures by means of the dominant dynamic recrystallization processes: bulging recrystallization (BLG) at $280-400{ }^{\circ} \mathrm{C}$ and subgrain rotation recrystallization (SGR) at $400-500{ }^{\circ} \mathrm{C}$. However, SGR also occurs at lower temperatures. Since both deformation processes are evident for the Grafenau sample, but with a tendency towards dominant BLG we assume a deformation 
temperature between 300 and $400{ }^{\circ} \mathrm{C}$. Within the BLG zone, the mean grain size increases from approximately $5 \mu \mathrm{m}$ at $300{ }^{\circ} \mathrm{C}$ to $25 \mu \mathrm{m}$ at $400{ }^{\circ} \mathrm{C}$ (Stipp et al. 2002). When transferring this trend to the Grafenau sample (loc. 13), a deformation temperature of about $350{ }^{\circ} \mathrm{C}$ can be assumed. The relatively small subgrain and grain size in the Grafenau quartz points to relatively high stresses, which is also indicated by the presence of deformation lamellae (Stipp and Tullis 2003; Stipp et al. 2010). An upper temperature limit for the hydrothermal mineralization in segment $\mathrm{A}$ is constrained by conditions of host rock deformation in the mylonites (Fig. 3) which is estimated to be in the range of $400-450{ }^{\circ} \mathrm{C}$. Considering the time gap and presumed basement uplift between mylonitization and the latter hydrothermal Pfahl mineralization, a temperature of $350{ }^{\circ} \mathrm{C}$ as inferred from quartz microstructures seems to be a reasonable estimate. Since ongoing transtensional stress was sufficient to fracture phase I all along the Pfahl and cause brittle deformation at the transition of segments A and B (loc. 12, Fig. 8a-c), in segments B and C lower temperatures $\left(<250{ }^{\circ} \mathrm{C}\right)$ are concluded due to missing ductile deformation features.

The temperature of the hydrothermal fluid is estimated to be slightly higher or similar to the surrounding rocks, as fluids are interpreted to be equilibrated with the rocks below and around the mineralized zone (see "Fluid sources"). The fluid temperature at one location remains constant during successive mineralization events, which is shown by similar oxygen isotope compositions of quartz for all quartz phases at one location.

\section{Regional variations}

The segmentation of the Bavarian Pfahl was based on the local distribution of rocks that were affected by ductile and brittle deformation (mylonites and hydrothermal quartz) as well as their detailed fabric (Fig. 2). This segmentation has been confirmed by the orientation and microstructures of the quartz veins. The different temperatures during mineralization between segment A (Grafenau) and segments B and C support the idea of major lineaments that separate the segments within the Moldanubian basement.

In addition to that, oxygen isotopes and trace elements show regional variations within segments B and C. A significant trend occurs in oxygen isotopes with a decrease of $\delta^{18} \mathrm{O}_{\mathrm{qtz}}$ from location 1 in the NW to location 12 in the SE (Fig. 12). Due to quartz-water fractionation, this regional variation may be explained by (1) decreasing $\delta^{18} \mathrm{O}_{\text {fluid }}$ from NW to SE combined with a homogeneous mineralization temperature or by (2) homogeneous $\delta^{18} \mathrm{O}_{\text {fluid }}$ combined with an increasing mineralization temperature from $\mathrm{NW}$ to $\mathrm{SE}$ (Fig. 12):
1. Constant mineralization temperatures of $250{ }^{\circ} \mathrm{C}$ require maximum $\delta^{18} \mathrm{O}_{\text {fluid }}$ between $+5 \%$ in the NW and $-1 \%$ o in the SE. A decreasing $\delta^{18} \mathrm{O}_{\text {fluid }}$ could be attributed to a southward-increasing influence of meteoric 'light' water. Since storage and heating of meteoric water by the crust would lead to isotope equilibration with the host rocks, the influence of meteoric water is unlikely to explain the regional trend of $\delta^{18} \mathrm{O}_{\mathrm{qtz}}$.

2. When assuming a homogeneous hydrothermal fluid with constant $\delta^{18} \mathrm{O}_{\text {fluid }}$, a temperature difference of about $90{ }^{\circ} \mathrm{C}$ between the NW $\left(160{ }^{\circ} \mathrm{C}\right)$ and the SE $\left(250{ }^{\circ} \mathrm{C}\right)$ edge is needed to produce a difference of about $5 \%$ for $\delta^{18} \mathrm{O}_{\mathrm{qtz}}$. An isotopically homogeneous fluid is supported by the fact that successive quartz phases show the same $\delta^{18} \mathrm{O}_{\mathrm{qtz}}$ at one location. Increasing temperatures could indicate the exposure of deeper crustal levels in the SE, due to different uplift of Moldanubian basement blocks.

Calculated $\delta^{18} \mathrm{O}_{\text {fluid }}$ at Grafenau (segment A) of 1.6-3.2\%o indicate that fluid isotopic composition is controlled by a different host rock isotopic composition or a different fractionation. This supports the exposure of a deeper crustal level in segment $\mathrm{A}$, which is dominated by migmatites and I-type granites (Siebel et al. 2012), compared to segments $\mathrm{B}$ and $\mathrm{C}$, which are dominated by paragneisses, diatexites and S-type granites.

The regional increase of maximum contents of $\mathrm{Sr}, \mathrm{Rb}$, $\mathrm{Ba}, \mathrm{Cs}, \mathrm{Li}, \mathrm{Ni}, \mathrm{V}$ and $\mathrm{Pb}$ in phase I towards NW (Fig. 10) indicates increasing amounts of accessory minerals within the fine-grained quartz. Therefore, interaction with the host rock might also be influenced by the mineralization temperature: higher mineralization temperatures in the SE lead to more effective silicification, whereas lower temperatures in the NW result in greater influence of the host rock. However, regional increase of $\mathrm{Li}$ and $\mathrm{Sr}$ in phase II reflects fluid enrichment towards NW.

\section{Fluid sources}

Early studies propose a magmatic origin of the fluids released from late-stage Variscan granite intrusions (Bauberger and Streit 1982) but the long time span between granite intrusion (328-321 Ma, Siebel et al. 2008) and quartz formation (247 $\pm 21 \mathrm{Ma}$, Horn et al. 1986) suggests that both events are independent. The tectonic origin of the hydrothermal fluids proposed by Behr and Horn (1983) is confirmed by similar initial Sr isotope compositions of Pfahl quartz and host rocks (Horn et al. 1986). PAAS-normalized flat REE patterns and $\mathrm{La} / \mathrm{Ce}$ ratios of $0.8-1.5$ for Bavarian Pfahl quartz (Fig. 11) are consistent with REE contents of Variscan granites and palites from Siebel et al. (2008), Chen et al. (2003) and Siebel et al. (2005). Therefore, fluid sources are to be found in the upper crust, thus, the Moldanubian 
basement, where tectonic stresses are released by faulting which induces fluid mobilization (Sibson et al. 1975). Oxygen isotopes can potentially help to identify fluid sources, regarding a magmatic, metamorphic, sedimentary or meteoric origin (Taylor 1974). Simon and Hoefs (1993) analyzed vein quartz in gneisses at the KTB site, showing $\delta^{18} \mathrm{O}$ of $12-13 \%$, and suggested that the related fluids were completely equilibrated with the host rocks. Variscan gneisses from the KTB drilling (Simon and Hoefs 1993) and from the Schwarzwald (Hoefs and Emmermann 1983) and S-type granites (Taylor 1978; Hoefs and Emmermann 1983) show $\delta^{18} \mathrm{O}$ values of $9-13 \%$. Similar host rocks and isotopic compositions of quartz veins at the Bavarian Pfahl propose fluid evolution buffered by the Moldanubian basement. The varying negative to missing $\mathrm{Ce}$ anomalies in quartz may be attributed to different oxidation states of the siliceous fluids, because negative $\mathrm{Ce}$ anomalies point to more oxidizing conditions (Monecke et al. 2002; Dill et al. 2011).

The trace element content of the Wölsendorf quartz resemble that of quartz phase I from the Pfahl in having relatively high concentrations of $\mathrm{Sr}, \mathrm{Ce}$ and $\mathrm{Ba}$ (Fig. 9), but the Wölsendorf quartz has higher $\mathrm{U}$ and Li concentrations than the Pfahl quartz. Since the Wölsendorf fluorite deposit also contains $U$ minerals, we suggest that the high $\mathrm{U}$ contents in quartz reflect $\mathrm{U}$ enrichment of the fluids. The REE contents of hydrothermal fluorites from Wölsendorf have been analyzed in detail by Dill et al. (2011), who conclude that leaching of granitic and gneissic basement rocks led to the enrichment of the deposit forming fluids. Whereas fluids leaching granites have negative Eu anomalies, fluids leaching gneisses form positive Eu anomalies (Schwinn and Markl 2005; Dill et al. 2012). Additionally, fluorite with relatively low $\mathrm{Sr}$ and high $\mathrm{Nd}$ isotope ratios were interpreted to have formed from granitic sources (Dill et al. 2012). The similar REE patterns of blue fluorite, quartz from Wölsendorf, and the surrounding Neunburg granite support the model of a granitic source of the Wölsendorf fluids (Fig. 11). Enrichment of F, Li, and U in hydrothermal fluids related to felsic magmas is known from the Variscan Erzgebirge where numerous mineralizations exist (e.g., Förster et al. 1999). Alternatively, Permian volcanism may have influenced the formation of the fluorite deposit: it is located in proximity to the Schmidgaden trough, a remnant of previously larger Permo-Carboniferous sediment basins that consist dominantly of clastic and carbonatic sediments (Schröder et al. 1997), but also contain Permian rhyolites in the Weiden area (Dill 1991, 1994). The large reservoir of fluorine in the Wölsendorf segment may be related to leaching of such rhyolites similar to the association of the Gawler silicic volcanic rocks and the fluorite-rich Olympic Dam deposit (Agangi et al. 2010; McPhie et al. 2011). Synsedimentary fault activity at the basin margins could have enabled mixing of fluids from basement and sedimentary sources. The influence of sedimentary brines has also been proposed by Peucker-Ehrenbrink and Behr (1993) for Bavarian Pfahl quartz due to a low-temperature, high-salinity fluid found in primary fluid inclusions. Element enrichment at the NW edge of the Bavarian Pfahl may also indicate fluid mixing. The enrichment of Wölsendorf fluids in $\mathrm{F}, \mathrm{U}$, and Li compared to those precipitating Pfahl quartz suggests restricted interaction between both hydrothermal systems. Nevertheless, similar mineralization ages, similar initial Sr isotope ratios (Horn et al. 1986) and spatial proximity imply a genetic relationship between both.

\section{Kinematics of faulting and related mineralization}

During the late Permian and early Triassic, large parts of the Variscan basement were already extensively eroded (Franke et al. 2000; Paul and Schröder 2012) and deposited in Rotliegend basins. In Upper Permian (Zechstein) to Lower Triassic times the Mid-European continental crust was under extension which could have triggered transtensional movements along the Pfahl shear zone. An intimate relationship between faulting and mineralization is also supported by age data from illite, grown during fluid infiltration along the Pfahl-parallel Danube fault zone (Ar/Ar 266-255 Ma, Siebel et al. 2010). Hydrothermal processes in a magmaticepithermal regime (White and Hedenquist 1990; Fournier 1999) or from metamorphic devolatilization during regional metamorphism (Yardley 1983; Connolly 2010) can be ruled out in the case of the Pfahl mineralization because of the time gap with respect to the Variscan orogeny (Ar/Ar cooling ages of K-feldspar <310 Ma, Kalt et al. 2000). Crystalline rocks of the cooled Moldanubian basement possess high crustal strength and will show seismic behavior in response to tectonic forces.

A mechanism to supply large volumes of fluid from lower to upper parts of the seismogenic crust has been proposed by Sibson et al. (1975). The so-called seismic pumping is driven by stress increase and generation of microcracks before peak strength of the rock is reached. Pressure gradients force fluids to migrate from host rocks into the cracks. When the rock fails, fluid is driven out and migrates upwards along the fault zone. At depths below the commonly inferred brittle-ductile transition (BDT, ca. $15 \mathrm{~km}$ ), brittle deformation and formation of microcracks can also occur in response to high strain rates (e.g., Wehrens et al. 2016). This mechanism has been confirmed by monitoring shear wave splitting during seismic events which enable to record changes in microcrack geometry during stress accumulation before an earthquake occurs (Crampin 1978). Variations in the buildup of stress and fluid saturation of stress-aligned microcracks before earthquakes can be recognized by changes in shear wave splitting (Crampin 1994; Crampin and Zatsepin 1997). The observations suggest increasing cracking until a 
fracture criticality limit is reached, shear strength is lost, and the earthquake occurs (Gao and Crampin 2008). Exhumed fault zones show evidence for fracture healing by pulses of hot fluids (Bestmann et al. 2016). The deformation lamellae in the Grafenau quartz veins (segment A) can be related to the quasi-instantaneous coseismic loading and the small recrystallized grain size can be related to postseismic stress relaxation (Trepmann et al. 2007).

To explain the regional difference in structure along the Pfahl Zone (Fig. 2), Hofmann (1962) suggested a deeper exposure of the southeastern Pfahl segments. This contention is supported by our temperature estimations based on microstructural observations (Fig. 8) and oxygen isotopes (Fig. 12). Taking into account that segment A exposes a different crustal depth section as compared to the northernmost segments (B, C), a model for mineralization of this large-scale mineralized structure is proposed and sketched in Fig. 14. This model suggests that focused fluid flow in the lower part of the Pfahl system is restricted to the preexisting shear zone (Grafenau setting). Above the BDT in the uppermost part of the crust, infiltration and silicification of host rock occur (phase I, Fig. 14). Fractured and cataclastic fabrics are sealed by infiltration of quartz, thus forming an impermeable cap above the vertical fault structure. Ongoing transtensional movements cause deformation of quartz I (ductile in loc. 13, brittle in loc. 12) and trigger further fluid migration causing a rise of the fluid pressure and finally the fluid breaks through the sealed and impermeable rocks by hydraulic fracturing (phases II, III, Fig. 14).

From the low-temperature exhumation history subsequent to the Pfahl mineralization there is no indication for differential vertical block movements in the younger geological history (post-Alpine), the presently exposed crust was in the same temperature range $\left(60-120^{\circ} \mathrm{C}\right)$ during the late Cretaceous (Vamvaka et al. 2014). From gravity maps there is indication for large-scale block segmentation of the Moldanubian basement in the Bavarian Forest. The Bavarian Pfahl separates the anatectic rocks of the Vorderer Bayerischer Wald with a more pronounced negative Bouguer anomaly from the dominating cordierite-garnet-bearing diatexites of
Fig. 14 Three-dimensional model of the formation of the three successive mineralization phases along the Bavarian Pfahl. Uplift and erosion led to the exposure of the marked depth levels in different segments (A, B, C) of the Bavarian Pfahl. The plot shows the evolution of the pore pressure during fluid ascent of phases II and III. As soon as the pore pressure exceeds the lithostatic pressure, hydraulic fracturing occurs. $\sigma_{H}$ hydrostatic pressure, $\sigma_{L}$ lithostatic pressure, $P_{f}$ fluid pressure, $B D T$ brittle-ductile transition
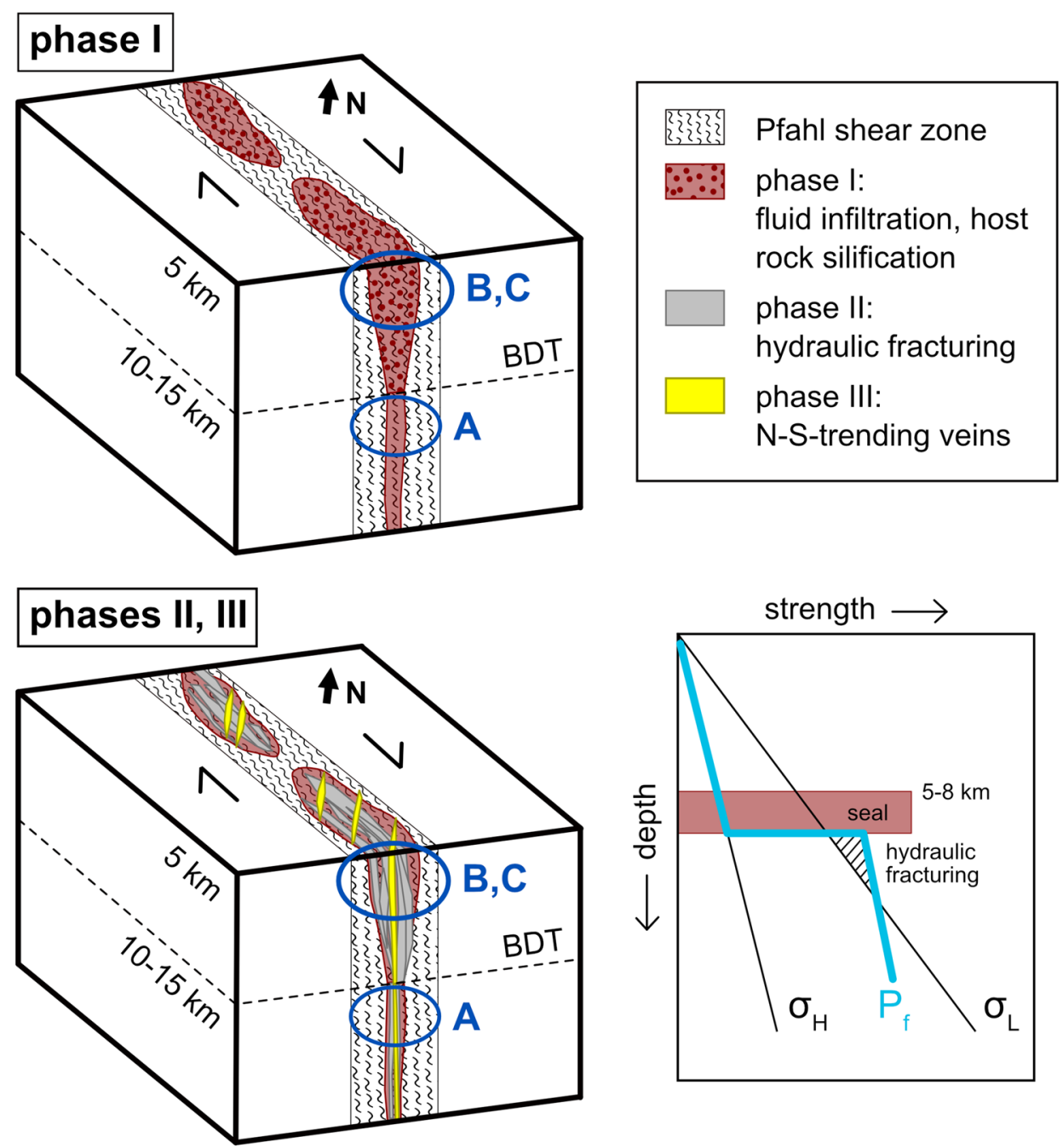
Fig. 15 Bouguer anomaly map of the study area with isoline distance of $2 \mathrm{mGal}$ (data from Skiba et al. 2010). Mafic rocks of the Teplá-Barrandium (TB) and the Zone Erbendorf Vohenstrauß (ZEV) create the dominant gravity highs, whereas the Moldanubian basement with southwards increasing sediment thickness shows a decreasing gravity. The Bavarian Pfahl forms a chain of local negative gravity anomalies within the Moldanubian basement. The gravity anomalies SW of the Pfahl support the segmentation (A, B, C) of the Moldanubian basement into different crustal blocks

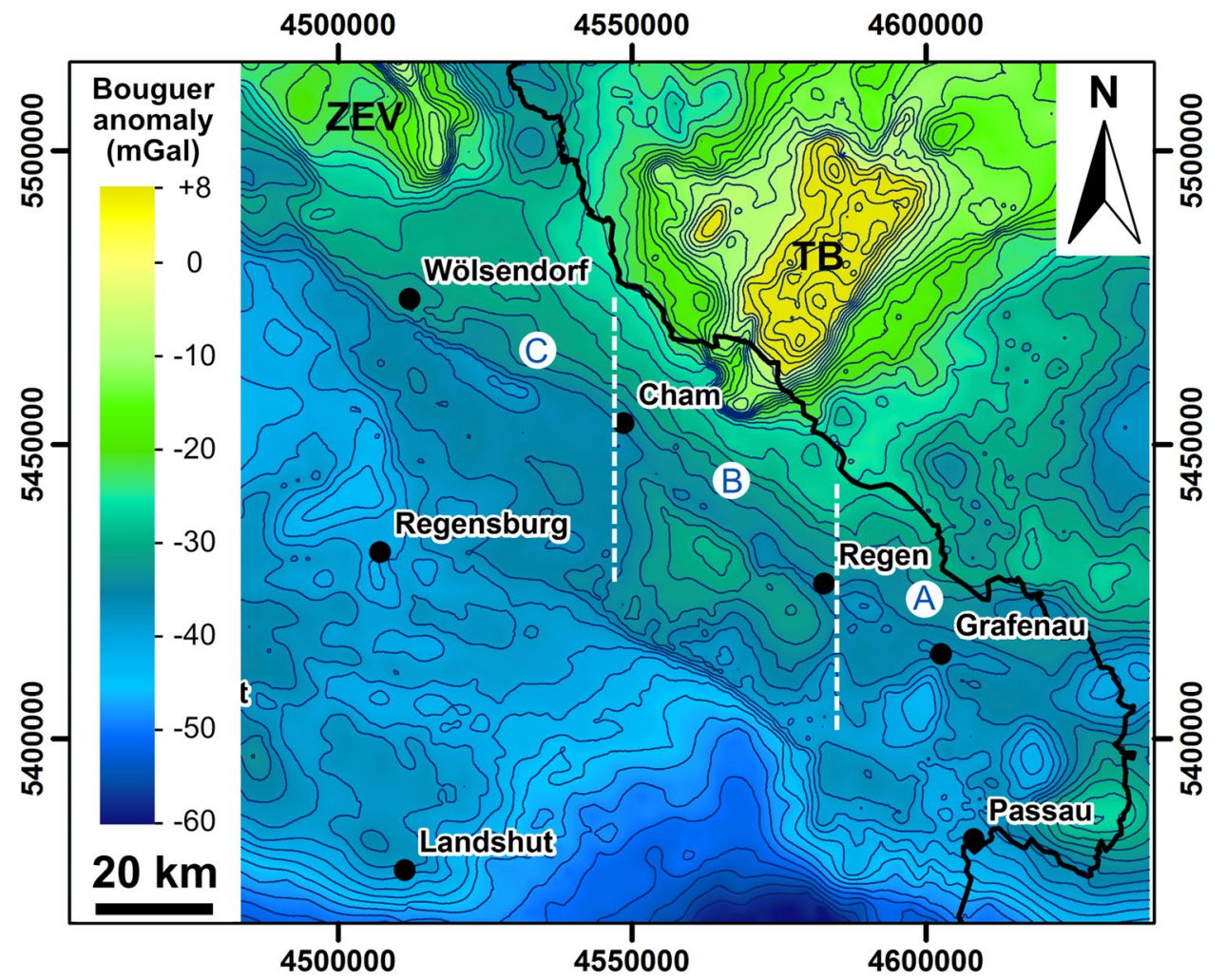

the Hinterer Bayerischer Wald with a less pronounced negative anomaly. Furthermore, N-S trending lineaments cut the basement into areas of different gravity signal (Fig. 15). The lineaments can be interpreted as crustal scale fault structures separating different crustal blocks of individual lithological characteristics. The coincidence of block boundaries and segmentation of the Pfahl structure is evident and maybe this segmentation is initiated during post-Variscan wrench-faulting. Similar structures have been observed in relationship to the Elbe lineament (Scheck et al. 2002). More detailed analysis of lineament structures and their significance for the different gravity field is currently under work.

\section{Conclusions}

A combined microstructural and geochemical study on mylonites and quartz veins of the Bavarian Pfahl gives detailed insight into the mechanisms, fluid and temperature conditions during quartz mineralization.

- Bavarian Pfahl mylonites formed the pathway for ascending fluids. The mylonites were formed by dextral strikeslip deformation under fluid influence and temperatures of about $400-450{ }^{\circ} \mathrm{C}$ as inferred from quartz microstructures in the SE part of the Pfahl.

- During a first hydrothermal event, the infiltration of silica-rich fluids into the shear zone led to the formation of a fine-grained, colored quartz mass with finely distributed accessory minerals. This quartz lode was fractured by two phases of pure, coarse-grained quartz veins, parallel and oblique to the Pfahl trend.

- Hydrothermal fluids from the upper crust were activated by seismic pumping and ascended along the preexisting shear zone. Cryptocrystalline quartz phases, resulting from a colloidal silica gel, alternate with large crystal growth, fracturing and sealing. This led to a complex internal structure of quartz, best visible on SEM-CL images.

- For the northwestern and central part of the Bavarian Pfahl, temperatures during mineralization were below $250{ }^{\circ} \mathrm{C}$, with a temperature increase from $\mathrm{NW}$ to $\mathrm{SE}$, indicated by decreasing $\delta^{18} \mathrm{O}$. In the SE part of the Pfahl, deformation features suggest higher temperatures of about $350{ }^{\circ} \mathrm{C}$ during mineralization and deformation at Grafenau. This supports the exposure of a deeper crustal level of Moldanubian crust south of Regen.

Acknowledgements Timo Spörlein, Volker Friedlein and Johannes Rohrmüller (LfU Hof) are thanked for their support and discussion. The help of Lars Scharfenberg in graphics and his support in GIS is gratefully acknowledged. This study was funded within the scope of "Bodenatlas Bayern" by the State Bavaria with co-financing of the European Union (EFRE-Programm Bayern 2014-2020). Two anonymous reviewers are thanked for their constructive comments, which helped us to improve the manuscript. 
Open Access This article is distributed under the terms of the Creative Commons Attribution 4.0 International License (http://creativeco mmons.org/licenses/by/4.0/), which permits unrestricted use, distribution, and reproduction in any medium, provided you give appropriate credit to the original author(s) and the source, provide a link to the Creative Commons license, and indicate if changes were made.

\section{References}

Agangi A, Kamenetsky VS, McPhie J (2010) The role of fluorine in the concentration and transport of lithophile trace elements in felsic magmas: insights from the Gawler Range Volcanics, South Australia. Chem Geol 273:314-325

Bauberger W, Streit R (1982) Geologische Karte von Bayern 1:25 000, Erläuterungen zum Blatt Nr. 6538 Schmidgaden. Bayerisches Geologisches Landesamt

Behr HJ, Horn EE (1983) Schlussfolgerungen für die postvariskischen Mineralisationen aus der Untersuchung von Flüssigkeitseinschlüssen. Fortschr Miner 61:19-20

Bestmann M, Pennacchioni G, Mostefaoui S, Göken M, de Wall H (2016) Instantaneous healing of micro-fractures during coseismic slip: evidence from microstructure and $\mathrm{Ti}$ in quartz geochemistry within an exhumed pseudotachylite-bearing fault in tonalite. Lithos 254-255:84-93

Bons PD (2001) The formation of large quartz veins by rapid ascent of fluids in mobile hydrofractures. Tectonophysics 336:1-17

Brandmayr M, Dallmeyer RD, Handler R, Wallbrecher E (1995) Conjugate shear zones in the Southern Bohemian Massif (Austria): implications for Variscan and Alpine tectonothermal activity. Tectonophysics 248:97-116

Brandmayr M, Loizenbauer J, Wallbrecher E (1999) Contrasting $\mathrm{P}-\mathrm{T}$ conditions during conjugate shear zone development in the Southern Bohemian Massif, Austria. Mitt Österr Geol Ges 90:11-29

Chen F, Siebel W, Satir M (2003) Geochemical and isotopic composition and inherited zircon ages as evidence for lower crustal origin of two Variscan S-type granites in the NW Bohemian massif. Int J Earth Sci 92:173-184

Clayton RN, O’Neil JR, Mayeda TK (1972) Oxygen isotope exchange between quartz and water. J Geophys Res 77:3057-3067

Connolly JAD (2010) The mechanics of metamorphic fluid expulsion. Elements 6:165-172

Crampin S (1978) Seismic-wave propagation through a cracked solid: polarization as a possible dilatancy diagnostic. Geophys J Int 53:467-496

Crampin S (1994) The fracture criticality of crustal rocks. Geophys J Int 118:428-438

Crampin S, Zatsepin SV (1997) Modelling the compliance of crustal rock-II. Response to temporal changes before earthquakes. Geophys J Int 129:495-506

Dahm T (2000) Numerical simulations of the propagation path and the arrest of fluid-filled fractures in the Earth. Geophys J Int 141:623-638

Derez T, Pennock G, Drury M, Sintubin M (2015) Low-temperature intracrystalline deformation microstructures in quartz. Geology $71: 3-23$

Dill HG (1991) Volcanic and Volcaniclastic Rocks at the Southwestern Edge of the Bohemian Massif. Zeitschrift für Geol Wissenschaften 5:519-537

Dill HG (1994) The evolution of the intermontane basins during Permo-Carboniferous at the western edge of the Bohemian Massif. Environment of deposition and economic geology. Acta Geol Hungarica 37:77-96
Dill HG, Weber B (2010) Variation of color, structure and morphology of fluorite and the origin of the hydrothermal F-Ba deposits at Nabburg-Wölsendorf, SE Germany. J Mineral Geochem 187:113-132

Dill HG, Hansen BT, Weber B (2011) REE contents, REE minerals and $\mathrm{Sm} / \mathrm{Nd}$ isotopes of granite- and unconformity-related fluorite mineralization at the western edge of the Bohemian Massif: with special reference to the Nabburg-Wölsendorf District, SE Germany. Ore Geol Rev 40:132-148

Dill HG, Weber B, Eigler G, Kaufhold S (2012) The fluorite deposits NE of Regensburg, SE Germany-a mineralogical and chemical comparison of unconformity-related fluorite vein-type deposits. Geochemistry 72:261-278

El-Naby HHA (2008) Genesis of secondary uranium minerals associated with jasperoid veins, El Erediya area, Eastern Desert, Egypt. Miner Depos 43:933-944

Fitz Gerald J, Stünitz H (1993) Deformation of granitoids at low metamorphic grade. I: Reactions and grain size reduction. Tectonophysics 221:269-297

Förster H-J, Tischendorf G, Trumbull RB, Gottesmann B (1999) Late-collisional granites in the Variscan Erzgebirge, Germany. J Petrol 40:1613-1645

Fournier RO (1999) The behavior of silica in hydrothermal solution. Rev Econ Geol 94:1193-1211

Franke W, Haak V, Oncken O, Tanner D (2000) Orogenic processes: quantification and modelling in the Variscan belt. Special publications, vol 179. Geological Society, London, pp 1-3

Freund S, Beier C, Krumm S, Haase KM (2013) Oxygen isotope evidence for the formation of andesitic-dacitic magmas from the fast-spreading Pacific-Antarctic Rise by assimilation-fractional crystallisation. Chem Geol 347:271-283

Fuchs HK, Soffel H (1981) Untersuchungen am Westabbruch der Böhmischen Einheit im oberfränkisch-oberpfälzischen Bruchschollenland mit Hilfe der Gravimetrie. N Jahrb Geol Paläont 161/162:183-210

Fynn GW, Powell WJA (1979) The cutting and polishing of electrooptic materials. Hilger, Bristol

Galadí-Enríquez E, Dörr W, Zulauf G, Galindo-Zaldívar J, Heidelbach F, Rohrmüller J (2010) Variscan deformation phases in the southwestern Bohemian Massif: new constraints from sheared granitoids. Zeitschrift der Dtsch Gesellschaft für Geowissenschaften 161:1-23

Gao Y, Crampin S (2008) Shear-wave splitting and earthquake forecasting. Terra Nov 20:440-448

Genske FS, Beier C, Haase KM, Turner SP, Krumm S, Brandl PA (2013) Oxygen isotopes in the Azores islands: crustal assimilation recorded in olivine. Geology 41:491-494

Gerler J (1990) Geochemische Untersuchungen an hydrothermalen, metamorphen, granitischen und pegmatitischen Quarzen und deren Flüssigkeitseinschlüssen. PhD thesis, Univ. Göttingen

Götze J, Plötze M, Graupner T, Hallbauer DK, Bray CJ (2004) Trace element incorporation into quartz: a combined study by ICPMS, electron spin resonance, cathodoluminescence, capillary ion analysis, and gas chromatography. Geochim Cosmochim Acta 68:3741-3759

Gromes N (1980) Geologische und mikrothermometrische Untersuchungen zur Mineralisation des Bayerischen Pfahles. Diploma thesis, Univ. Göttingen

Handy MR, Hirth G, Bürgmann R (2007) Continental fault structure and rheology from the frictional-to-viscous transition downward. In: Handy MR, Hirth G, Hovius N (eds) Tectonic faults: agents of change on a dynamic earth. MIT press, Cambridge, Massachusets, London, pp 139-181

Herrington RJ, Wilkinson JJ (1993) Colloidal gold and silica in mesothermal vein systems. Geology 21:539-542 
Hoefs J, Emmermann R (1983) The oxygen isotope composition of Hercynian granites and pre-Hercynian gneisses from the Schwarzwald, SW Germany. Contrib Mineral Petrol 83:320-329

Hofmann R (1962) Die Tektonik des Bayerischen Pfahls. Geol Rundschau 52:332-346

Horn P, Köhler H, Müller-Sohnius D (1986) Rb-Sr-Isotopengeochemie hydrothermaler Quarze des Bayerischen Pfahles und eines Flusspat-Schwerspatganges von Nabburg-Wölsendorf/ Bundesrepublik Deutschland. Chem Geol Isot Geosci Sect 58:259-272

Horstman EL (1957) The distribution of lithium, rubidium and caesium in igneous and sedimentary rocks. Geochim Cosmochim Acta $12: 1-28$

Hoskin PWO (2005) Trace-element composition of hydrothermal zircon and the alteration of Hadean zircon from the Jack Hills, Australia. Geochim Cosmochim Acta 69:637-648

Ibrahim ME, Zalata AA, Assaf HS, Ibrahim IH, Rashed MA (2005) El Sella shear zone, Southeastern Desert, Egypt; an example of vein-type uranium deposit. In: The 9th international mining, petroleum, and metallurgical engineering conference, Cairo University, Egypt, pp 41-55

Ihinger PDP, Zink SIS (2000) Determination of relative growth rates of natural quartz crystals. Nature 404:865

Jourdan A-L, Vennemann TW, Mullis J, Ramseyer K, Spiers CJ (2009) Evidence of growth and sector zoning in hydrothermal quartz from Alpine veins. Eur J Mineral 21:219-231

Kalt A, Corfu F, Wijbrans JR (2000) Time calibration of a P-T path from a Variscan high-temperature low-pressure metamorphic complex (Bayerische Wald, Germany), and the detection of inherited monazite. Contrib Mineral Petrol 138:143-163

Klemme S, Prowatke S, Hametner K, Günther D (2005) Partitioning of trace elements between rutile and silicate melts: implications for subduction zones. Geochim Cosmochim Acta 69:2361-2371

Landtwing MR, Pettke T (2005) Relationships between SEMcathodoluminescence response and trace-element composition of hydrothermal vein quartz. Am Mineral 90:122-131

Leipziger K (1986) Untersuchungen zur Raumschaffung der Fluoritmineralisation im Wölsendorfer Flußspatrevier. PhD thesis, Univ. Mainz

Lovering T (1972) Jasperoid in the United States; its characteristics, origin, and economic significance. US Government Printing Office, Washington

Marshall DJ, Mariano AN (1988) Cathodoluminescence of geological materials. Unwin Hyman, Boston

Mattern F (2001) Permo-Silesian movements between Baltica and western Europe: tectonics and 'basin families'. Terra Nov 13:368-375

McPhie J, Kamenetsky V, Allen S, Ehrig K, Agangi A, Bath A (2011) The fluorine link between a supergiant ore deposit and a silicic large igneous province Jocelyn. Geology 39:1003-1006

Menegon L, Pennacchioni G, Stünitz H (2006) Nucleation and growth of myrmekite during ductile shear deformation in metagranites. J Metamorph Geol 24:553-568

Meyer RKF (1989) Die Entwicklung der Pfahl-Störungszone und des Bodenwöhrer Halbgrabens auf Blatt Wackerdorf. Erlanger geol Abh 117:1-24

Monecke T, Kempe U, Götze J (2002) Genetic significance of the trace element content in metamorphic and hydrothermal quartz: a reconnaissance study. Earth Planet Sci Lett 202:709-724

Oppermann R (1990) Mikrothermometrie- und KathodolumineszenzUntersuchungen an Quarzen des Bayerischen Pfahles. Diploma thesis, Univ. Göttingen

Paul J, Schröder B (2012) Rotliegend im Ostteil der Süddeutschen Scholle. Schriftenr der Dtsch Gesellschaft für Geowissenschaften 61:697-706
Peucker-Ehrenbrink B, Behr H-J (1993) Chemistry of hydrothermal quartz in the post-Variscan Bavarian Pfahl system, F.R. Germany. Chem Geol 103:85-102

Ramsay JG (1980) The crack-seal mechanism of rock deformation. Nature 284:135-139

Rusk BG, Lowers HA, Reed MH (2008) Trace elements in hydrothermal quartz: relationships to cathodoluminescent textures and insights into vein formation. Geology 36:547-550

Scheck M, Bayer U, Otto V, Lamarche J, Banka D, Pharaoh T (2002) The Elbe Fault System in North Central Europe-a basement controlled zone of crustal weakness. Tectonophysics 360:281-299

Schröder B (1987) Inversion tectonics along the Western margin of the Bohemian Massif. Tectonophysics 137:93-100

Schröder B, Ahrendt H, Peterek A, Wemmer K (1997) Post-Variscan sedimentary record of the SW margin of the Bohemian massif: a review. Geol Rundschau 86:178-184

Schwinn G, Markl G (2005) REE systematics in hydrothermal fluorite. Chem Geol 216:225-248

Seward TM, Williams-Jones AE, Migdisov AA (2013) The chemistry of metal transport and deposition by ore-forming hydrothermal fluids. In: Turekian K, Hollan H (eds) Treatise on geochemistry, 2nd edn. Elsevier Inc., Oxford, pp 29-57

Sibson RH, Moore JMM, Rankin AH (1975) Seismic pumping-a hydrothermal fluid transport mechanism. J Geol Soc London 131:653-659

Siebel W, Blaha U, Chen F, Rohrmüller J (2005) Geochronology and geochemistry of a dyke-host rock association and implications for the formation of the Bavarian Pfahl shear zone, Bohemian Massif. Int J Earth Sci 94:8-23

Siebel W, Thiel M, Chen F (2006) Zircon geochronology and compositional record of late- to post-kinematic granitoids associated with the Bavarian Pfahl zone (Bavarian Forest). Mineral Petrol 86:45-62

Siebel W, Shang CK, Reitter E, Rohrmüller J, Breiter K (2008) Two distinctive granite suites in the SW Bohemian Massif and their record of emplacement: constraints from geochemistry and zircon ${ }^{207} \mathrm{~Pb} /{ }^{206} \mathrm{~Pb}$ chronology. J Petrol 49:1853-1872

Siebel W, Hann HP, Danišík M, Shang CK, Berthold C, Rohrmüller J, Wemmer K, Evans NJ (2010) Age constraints on faulting and fault reactivation: a multi-chronological approach. Int J Earth Sci 99:1187-1197

Siebel W, Shang CK, Thern E, Danišík M, Rohrmüller J (2012) Zircon response to high-grade metamorphism as revealed by $\mathrm{U}-\mathrm{Pb}$ and cathodoluminescence studies. Int $\mathrm{J}$ Earth Sci 101:2105-2123

Simmons SF, White NC, John DA (2005) Geological characteristics of epithermal precious and base metal deposits. Econ Geol 100:485-522

Simon K, Hoefs J (1993) O, H, C isotope study of rocks from the KTB pilot hole: crustal profile and constraints on fluid evolution. Contrib Mineral Petrol 114:42-52

Simpson C, Wintsch R (1989) Evidence for deformation-induced K-feldspar replacement by myrmekite. J Metamorph Geol 7:261-275

Skiba P, Gabriel G, Scheibe R, Seidemann O (2010) Schwerekarte der Bundesrepublik Deutschland 1:1 000 000. Leibnitz-Institut für Angewandte Geophysik, Hannover

Stipp M, Tullis J (2003) The recrystallized grain size piezometer for quartz. Geophys Res Lett 30:2088

Stipp M, Stünitz H, Heilbronner R, Schmid SM (2002) The eastern Tonale fault zone: a 'natural laboratory' for crystal plastic deformation of quartz over a temperature range from 250 to $700{ }^{\circ} \mathrm{C}$. J Struct Geol 24:1861-1884 
Stipp M, Tullis J, Scherwath M, Behrmann JH (2010) A new perspective on paleopiezometry: dynamically recrystallized grain size distributions indicate mechanism changes. Geology 38:759-762

Taylor HP (1974) The application of oxygen and hydrogen isotope studies to problems of hydrothermal alteration and ore deposition. Econ Geol 69:843-883

Taylor HP (1978) Oxygen and hydrogen isotope studies of plutonic granitic rocks. Earth Planet Sci Lett 38:177-210

Taylor SR, McLennan SM (1985) The continental crust: its composition and evolution. Blackwell Scientific Pub., Palo Alto

Teipel U, Galadí-Enríquez E, Glaser S, Kroemer E, Rohrmüller J (2008) Geologische Karte des Bayerischen Waldes 1:150 000. Bayerisches Landesamt für Umwelt

Trepmann C, Stöckhert B, Dorner D, Moghadam RH, Küster M, Röller K (2007) Simulating coseismic deformation of quartz in the middle crust and fabric evolution during postseismic stress relaxation-an experimental study. Tectonophysics 442:83-104

Urai JL, Means WD, Lister GS (1986) Dynamic recrystallization of minerals. In: Hobbs BE, Heard HC (eds) Mineral and rock deformation: laboratory studies. Geophysical monograph. American Geophysical Union (AGU), Washington, DC, pp 161-199

Vamvaka A, Siebel W, Chen F, Rohrmüller J (2014) Apatite fissiontrack dating and low-temperature history of the Bavarian Forest (southern Bohemian Massif). Int J Earth Sci 103:103-119

Wallbrecher VE, Dallmeyer RD, Brandmayr M, Handler R, Maderbacher F, Platzer R (1991) Kinematik und Alter der Blattverschiebungszonen in der südlichen Böhmischen Masse. In: Gattinger TE, Roetzel R (eds) Arbeitstagung. Geol. B.-A. Verlag d. Geologischen Bundesanstalt, Vienna, pp 35-48
Wark DA, Watson EB (2006) TitaniQ: a titanium-in-quartz geothermometer. Contrib Mineral Petrol 152:743-754

Wehrens P, Berger A, Peters M, Spillmann T, Herwegh M (2016) Deformation at the frictional-viscous transition: evidence for cycles of fluid-assisted embrittlement and ductile deformation in the granitoid crust. Tectonophysics 693:66-84

White S (1976) A Discussion on natural strain and geological structure-The effects of strain on the microstructures, fabrics, and deformation mechanisms in quartzites. Phil Trans R Soc Lond A 283:69-86

White S (1977) Geological significance of recovery and recrystallization processes in quartz. Tectonophysics 39:143-170

White NC, Hedenquist JW (1990) Epithermal environments and styles of mineralization: variations and their causes, and guidelines for exploration. J Geochem Explor 36:445-474

Wilkinson JJ, Stoffell B, Wilkinson CC, Jeffries TE, Appold MS (2009) Anomalously metal-rich fluids form hydrothermal ore deposits. Science 323:764-767

Yardley BWD (1983) Quartz veins and devolatilization during metamorphism. J Geol Soc Lond 140:657-663

Yilmaz TI, Prosser G, Liotta D, Kruhl JH, Gilg HA (2014) Repeated hydrothermal quartz crystallization and cataclasis in the Bavarian Pfahl shear zone (Germany). J Struct Geol 68:158-174

Zack T, Kronz A, Foley SF, Rivers T (2002) Trace element abundances in rutiles from eclogites and associated garnet mica schists. Chem Geol 184:97-122

Ziehr H (1975) Das Wölsendorfer Fluorit-Revier. Aufschluss Sonderband 26:207-242 